\title{
Astronomical time scale for the Middle Oxfordian to Late Kimmeridgian in the Swiss and French Jura Mountains
}

\author{
ANDRÉ STRASSER
}

Key words: Astronomical time scale, Cyclostratigraphy, Oxfordian, Kimmeridgian, Jura Mountains

\begin{abstract}
Detailed investigation of facies and sedimentary structures reveals that, during the Middle Oxfordian to Late Kimmeridgian, the shallow carbonate platform of the Swiss and French Jura Mountains recorded high-frequency sea-level fluctuations quite faithfully. The cyclostratigraphic analysis within the established biostratigraphic and sequence-chronostratigraphic framework implies that the resulting hierarchically stacked depositional sequences formed in tune with the orbital cycles of precession (20 kyr) and eccentricity (100 and 400 $\mathrm{kyr}$ ). The astronomical time scale presented here is based on the correlation of 19 platform sections and 4 hemipelagic sections from south-eastern France where good biostratigraphic control is available. The cyclostratigraphic interpretation suggests that the interval between sequence boundaries Ox4 and Kim1 (early Middle Oxfordian to earliest Kimmeridgian) lasted 3.2 myr and that the Kimmeridgian sensu gallico has a duration of 3.2 to $3.3 \mathrm{myr}$. The astronomical time scale proposed here is compared to time scales established by other authors in other regions and the discrepancies are discussed. Despite these discrepancies, there is a potential to estimate the durations of ammonite zones and depositional sequences more precisely and to better evaluate the rates of sedimentary, ecological and diagenetic processes.
\end{abstract}

\section{ZUSAMMENFASSUNG}

Die detaillierte Untersuchung von Fazies und Sedimentstrukturen zeigt, dass während des Mittleren Oxfords bis zum Späten Kimmeridge die flache Karbonatplattform des schweizerischen und französischen Juras hochfrequente Meeresspiegelschwankungen recht genau aufzeichnete. Die zyklostratigraphische Analyse innerhalb des bestehenden biostratigraphischen und sequenz-chronostratigraphischen Rahmens deutet darauf hin, dass sich die resultierenden hierarchisch gestapelten Ablagerungssequenzen im Einklang mit den orbitalen Zyklen der Präzession (20 ka) und der Exzentrizität (100 und $400 \mathrm{ka}$ ) bildeten. Der hier vorgestellte astronomische Zeitmassstab beruht auf der Korrelation von 19 Plattform-Profilen und 4 hemipelagischen Profilen aus Südost-Frankreich, wo eine gute biostratigraphische Kontrolle vorhanden ist. Gemäss der zyklostratigraphischen Interpretation dauerte das Intervall zwischen den Sequenzgrenzen Ox4 und Kim1 (frühes Mittleres Oxford bis frühestes Kimmeridge) 3.2 ma; das Kimmeridge sensu gallico hat eine Dauer von 3.2 bis $3.3 \mathrm{ma}$. Der hier vorgeschlagene astronomische Zeitmassstab wird mit Massstäben anderer Autoren in anderen Regionen verglichen und die Diskrepanzen werden diskutiert. Trotz dieser Diskrepanzen ergibt sich das Potential, die Dauer von Ammonitenzonen und Ablagerungssequenzen präziser abschätzen und die Geschwindigkeit von sedimentären, ökologischen und diagenetischen Prozessen besser evaluieren zu können.

\section{Introduction}

Since the early days of Earth Sciences there has been a quest for measuring geological time. Relative time scales have been established through biostratigraphy and are constantly being refined. Radiometric dating furnishes numerical ages but error margins may still be large. Astronomical time scales use the sedimentary or geochemical record of insolation changes and are directly linked to orbital periodicities with known durations (e.g., Fischer et al. 2004). Except for the Quaternary where other dating methods give yearly, decadal, or centennial time resolutions, astronomical time scales offer the highest resolution available for the deep geologic past. If the sedimentary systems were sensitive enough to record orbitally induced climate changes, and if the general time frame is constrained by radiometric dating, then a time resolution of 20'000 years (corresponding to the cycle of the precession of the equinoxes) can optimally be obtained (Hilgen et al. 2004; Strasser et al. 2007; see also examples in D'Argenio et al. 2004).

In this paper, an astronomical time scale covering the Middle Oxfordian to Late Kimmeridgian interval of the Swiss and French Jura Mountains is developed. There, the Oxfordian and Kimmeridgian have been studied extensively since the $19^{\text {th }}$ century (e.g., Thurmann 1830; Heer 1865). Lithology and biostratigraphy of these mostly shallow-water carbonates are well known (e.g., Thalmann 1966; Bolliger \& Burri 1970; Trümpy 1980; Gygi \& Persoz 1986; Enay et al. 1988; Gygi 1995; Gygi 2000). Furthermore, several high-resolution sequence-strati-

Department of Geosciences, University of Fribourg, Pérolles, 1700 Fribourg, Switzerland. E-mail: andreas.strasser@unifr.ch 


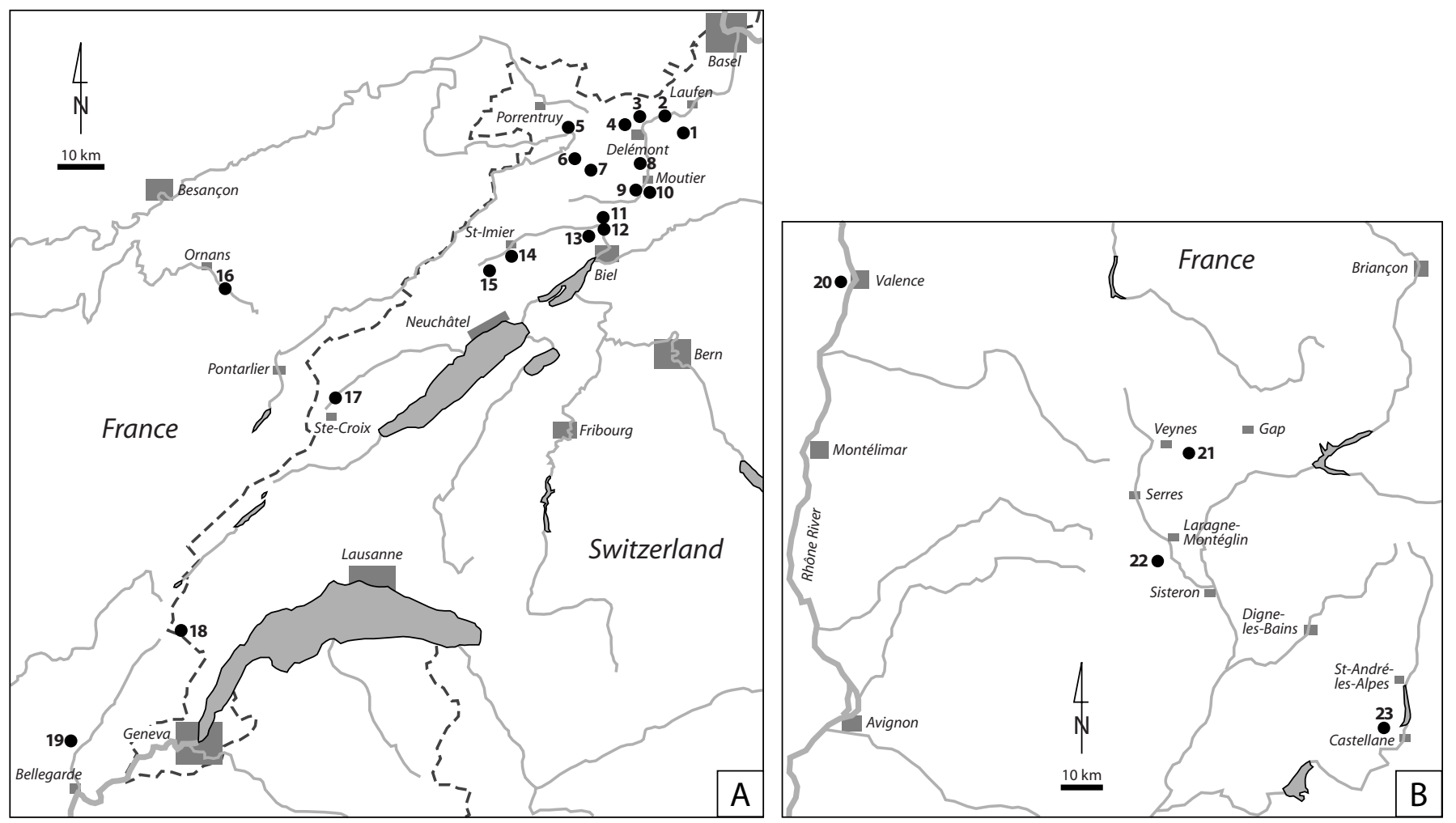

Fig. 1. Location of studied sections in the Swiss and French Jura (A) and in south-eastern France (B).

graphic and cyclostratigraphic studies have been undertaken in the last decade (e.g., Pittet 1996; Pittet \& Strasser 1998a, b; Mouchet 1998; Dupraz 1999; Strasser et al. 2000; Colombié 2002; Hug 2003; Jank 2004; Rameil 2005; Colombié \& Strasser 2005; Jank et al. 2006; Colombié \& Rameil 2007). The present work is a synthesis based on 23 sections (Fig. 1; Table 1) logged and interpreted by Pittet (1996), Bühler (1997), Oswald (1998), Bard (1999), Dupraz (1999), Gsponer (1999), Jordan (1999), Rauber (2001), Colombié (2002), Hug (2003) and Rameil (2005). The purpose of this endeavour is to offer a time frame within which the rates of sedimentological, ecological and diagenetic processes can be evaluated with unprecedented precision.

\section{Palaeogeographic and stratigraphic setting}

The studied time interval covers the Middle and Late Oxfordian, the Kimmeridgian (sensu gallico) and the earliest Tithonian. During those times, in the original position of today's Jura Mountains, a shallow platform extended between the Paris Basin to the north and the Tethys Ocean to the south. Palaeolatitude was about 26 to $27^{\circ} \mathrm{N}$ (Dercourt et al. 1993). Lagoonal facies rich in carbonate-producing organisms, coral patch-reefs and ooid shoals testify warm, subtropical waters. Water depths varied between a few tens of metres in the open lagoons to intertidal and supratidal along the coasts of low-lying islands.
Controlled by synsedimentary tectonics, epicontinental basins developed mainly to the south of the platform (Allenbach 2001). Periodically, especially during Oxfordian times, siliciclastics originating from the Bohemian and the Central massifs were shed onto the platform and into the basins (e.g., Gygi \& Persoz 1986; Pittet 1996), which implies generally more humid conditions. In the Kimmeridgian and Tithonian, siliciclastics are less abundant and evaporites occur, suggesting an evolution towards a generally more arid climate (Hug 2003; Rameil 2005).

The platform facies of the Swiss and French Jura is represented by 19 sections (Fig. 1), which include the St. Ursanne, Pichoux, Vellerat, Balsthal, Courgenay, Reuchenette and Twannbach formations and their respective members (Gygi 1995; Fig. 2). The Wildegg Formation, characterised by limestone-marl alternations, tempestites and condensed intervals, was deposited in an epicontinental basin. Based on ammonites and mineralo-stratigraphic correlations, Gygi \& Persoz (1986) and Gygi (1995) have established a solid biostratigraphic framework for these formations and members (Fig. 2A). Furthermore, Gygi et al. (1998) identified large-scale sequence boundaries, which correlate well with the ones recognized by Hardenbol et al. (1998) in several European basins. In order to additionally constrain the biostratigraphy, 4 sections from south-eastern France are integrated in this study (Fig. 1). They contain hemipelagic limestone-marl alternations and are well 
Table 1. Location, stratigraphic range and authors of sections used for the sequence- and cyclostratigraphic interpretation.

\begin{tabular}{|c|c|c|c|c|}
\hline $\begin{array}{l}\text { No. of } \\
\text { Section }\end{array}$ & Name & Location & Stratigraphic interval & Author(s) \\
\hline 1 & Les Champés & Along forest road SE of Bärschwil & Middle Oxfordian to Early Kimmeridgian & Rauber (2001) \\
\hline 2 & Liesberg & In quarry of cement factory & Late Oxfordian & Hug (2003) \\
\hline 3 & Mettemberg-Soyhières & Along road from Mettemberg to Soyhières & Late Oxfordian & Hug (2003) \\
\hline 4 & Vorbourg & Along road above Vorbourg chapel & Middle to Late Oxfordian & Pittet (1996) \\
\hline 5 & St-Ursanne & Along footpath and in cliff above St-Ursanne & Middle to Late Oxfordian & Oswald (1998) \\
\hline 6 & Tabeillon & Along path towards Sceut Dessous & Middle Oxfordian & Bühler (1997), Dupraz (1999) \\
\hline 7 & Pichoux & Along road between Undervelier and Sornetan & Middle Oxfordian to Late Kimmeridgian & Pittet (1996), Colombié (2002) \\
\hline 8 & Hautes Roches & $\begin{array}{l}\text { Along forest path south of the village of } \\
\text { Hautes Roches }\end{array}$ & Middle to Late Oxfordian & Pittet (1996), Dupraz (1999) \\
\hline 9 & Gorges de Court & Along road between Moutier and Court & Middle to Late Oxfordian & Pittet (1996), Colombié (2002), Hug (2003) \\
\hline 10 & Moutier & Borehole SE of Moutier & Middle to Late Oxfordian & Pittet (1996), Dupraz (1999) \\
\hline 11 & La Chamalle & Along forest road to La Chamalle farm & Late Oxfordian & Jordan (1999) \\
\hline 12 & Péry-Reuchenette & In quarry of cement factory & Middle Oxfordian to Late Kimmeridgian & Pittet (1996), Colombié (2002), Hug (2003) \\
\hline 13 & Forêt de Châtel & Along forest road & Late Oxfordian & Gsponer (1999) \\
\hline 14 & Savagnières & Along road between St-Imier and Val-de-Ruz & Middle to Late Oxfordian & Pittet (1996) \\
\hline 15 & Pertuis & Along road from Dombresson to Pertuis & Middle to Late Oxfordian & Pittet (1996) \\
\hline 16 & Châteauvieux-les-Fossés & Along road from Vuillafans to Longeville & Middle Oxfordian to Early Kimmeridgian & Bard (1999) \\
\hline 17 & Noirvaux & Along road from Buttes to Ste-Croix & Late Kimmeridgian to Late Tithonian & Rameil (2005) \\
\hline 18 & La Dôle & Along base of cliff below La Dôle summit & Late Kimmeridgian to Late Tithonian & Rameil (2005) \\
\hline 19 & Cirque des Avalanches & $\begin{array}{l}\text { Along forest road } \mathrm{N} \text { of Champfromier, below } \\
\text { Le Truchet }\end{array}$ & Middle Kimmeridgian to Early Tithonian & Rameil (2005) \\
\hline 20 & Crussol & In quarries at Montagne de Crussol & Kimmeridgian & Colombié (2002) \\
\hline 21 & Châteauneuf-d'Oze & $\begin{array}{l}\text { Along road between Veynes and Moulin-du- } \\
\text { Pied-de-la-Poua }\end{array}$ & Kimmeridgian & Colombié (2002) \\
\hline 22 & Gorges de la Méouge & $\begin{array}{l}\text { Along road between Barret-le-Bas and } \\
\text { Laragne-Montéglin }\end{array}$ & Late Oxfordian to Late Kimmeridgien & Colombié (2002) \\
\hline 23 & Clue de Taulanne & Along road from Barrème to Col des Leques & Late Kimmeridgian to Early Berriasian & Rameil (2005) \\
\hline
\end{tabular}

dated by ammonites (Atrops 1982). All sections have been chosen for their relative completeness of the sedimentary record and for their unequivocal stratigraphic position (Fig. 2B). These are the prerequisites for the cyclostratigraphical analysis.

\section{Material and methods}

The sections presented here (Figs. 3-12) cover a total of 1969 metres, have been logged at $\mathrm{cm}$-scale and are documented by a total of 2622 thin sections, polished slabs and marl washings. Where no samples were taken, the facies has been determined on the outcrop with a hand lens. Under the optical microscope or the binocular, microfacies have been analysed using the Dunham (1962) classification and a semi-quantitative estimation of the abundance of rock constituents (Fig. 3). Special attention has been paid to sedimentary structures and to omission surfaces (Clari et al. 1995; Hillgärtner 1998). The sum of this sedimentological information is then used to interpret the depositional environments. For the sequence-stratigraphic interpretation of the facies evolution, the nomenclature of Vail et al. (1991) is applied.

In the platform sections, vertical facies changes define deepening-shallowing depositional sequences, which are hierarchically stacked (example in Fig. 3). Elementary sequences are the smallest units where facies evolution indicates a cycle of environmental change, including sea-level change (Strasser et al. 1999). In some cases, there is no facies evolution discernable within a bed but marls or omission surfaces delimiting the bed suggest an environmental change (Strasser \& Hillgärtner 1998). Commonly, 2 to 7 elementary sequences compose a small-scale sequence, which generally displays a deepening then shallowing trend and exhibits the relatively shallowest fa- cies at its boundaries (Fig. 3). For example, birdseyes, microbial mats or penecontemporaneous dolomitization suggest tidal-flat environments, lithoclasts and black pebbles imply erosion of previously exposed and consolidated sediment (Strasser \& Davaud 1983), and detrital quartz and plant fragments indicate input from the hinterland during low relative sea level. In some cases, however, no changes in water depth are implied but a change to more open-marine fauna and an increase in energy points to a transgressive event (e.g., at metre 13.8 in Fig. 3). There, a transgressive surface delimits the small-scale sequence rather than a sequence boundary sensu Vail et al. (1991). Four small-scale sequences make up a medium-scale sequence, which again displays a general deeping-shallowing trend of facies evolution and the relatively shallowest facies at its boundaries. Furthermore, the elementary sequences are thinner around the small-scale and mediumscale sequence boundaries, which suggests reduced accommodation. Thick elementary sequences in the central parts of these sequences imply higher accommodation. The fact that most of the small-scale and medium-scale sequence boundaries can be followed over hundreds of kilometres points to an allocyclic control on sequence formation. However, also autocyclic processes (such as lateral migration of sediment bodies or reactivation of high-energy shoals) occurred and are recorded mainly on the level of the elementary sequences (Strasser 1991; Strasser \& Védrine 2007).

The basinal sections feature limestone-marl alternations, whereby one limestone-marl couplet is considered to correspond to an elementary sequence. In some cases, these are grouped into bundles of 5 that define small-scale sequences, which again build up medium-scale sequences. In other cases, the hierarchical stacking is not evident. 


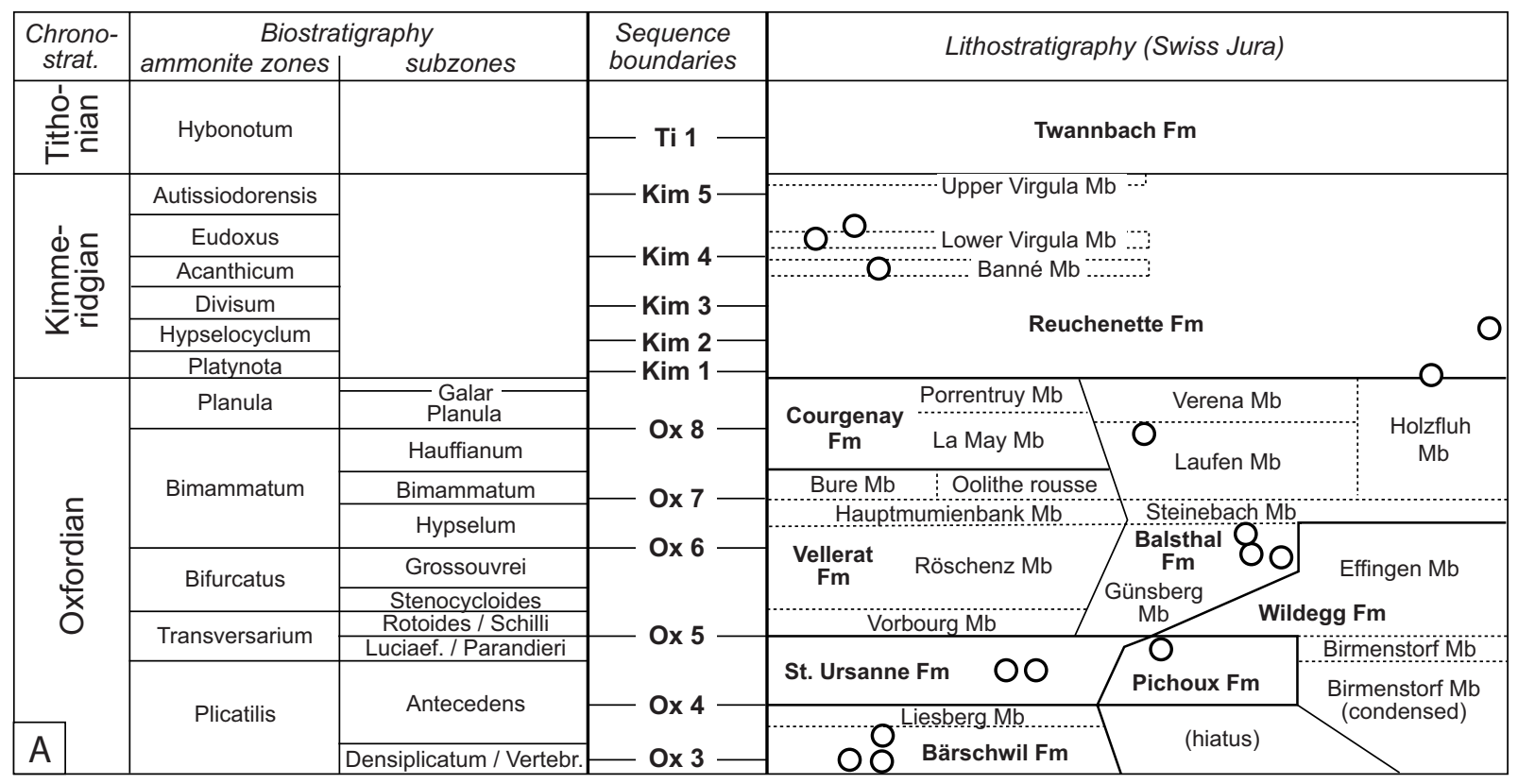

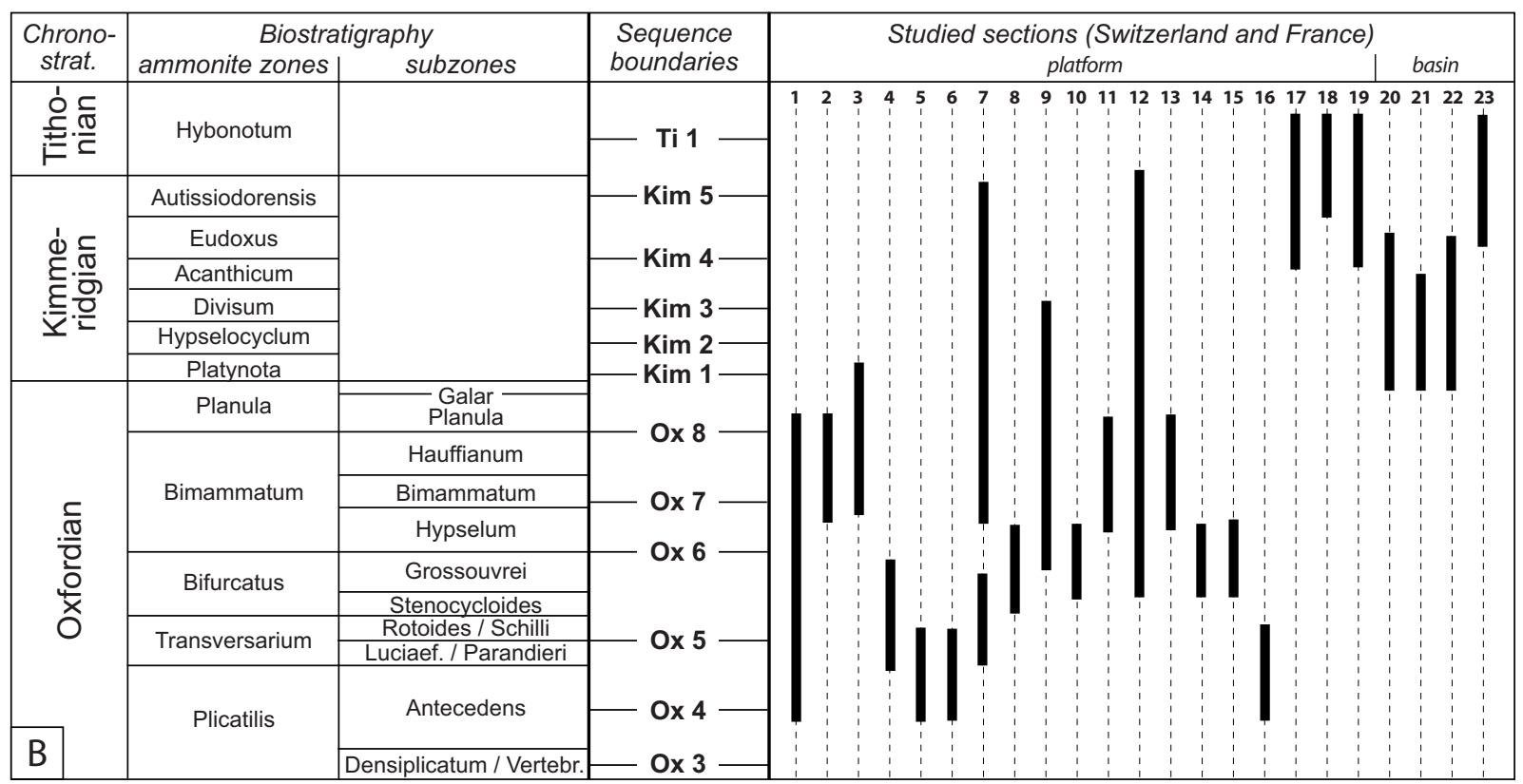

Fig. 2. (A) Chronostratigraphy biostratigraphy and lithostratigraphy of the studied interval. Litho- and biostratigraphic scheme after Gygi (1995, 2000), with circles indicating where biostratigraphically significant ammonites have been found. Sequence boundaries after Hardenbol et al. (1998) and Gygi et al. (1998). Note that the time scale is not indicated (compare with Fig. 13). Fm: formation; Mb: member. (B) Stratigraphic range of studied sections.

Each section is first interpreted independently (example in Fig. 3). Within the framework given by biostratigraphy and large-scale sequence stratigraphy (Fig. 2), the sections are then correlated on the level of small-scale and medium-scale depositional sequences. Some small- or medium-scale sequence boundaries defined in an isolated section may have to be reinterpreted and shifted by one or two elementary sequences in order to obtain a best-fit solution that satisfies the sedimento- logical observations as well as the general stratigraphic frame. In several cases it is not possible to attribute a small-scale or medium-scale sequence boundary to a specific bed surface: a sequence-boundary zone is then introduced, which covers the interval of relatively lowest accommodation space (Montañez \& Osleger 1993; Strasser et al. 1999). The same holds for maxmum-flooding situations, where highest accommodation gain on the shallow platform is not always translated by a specific 


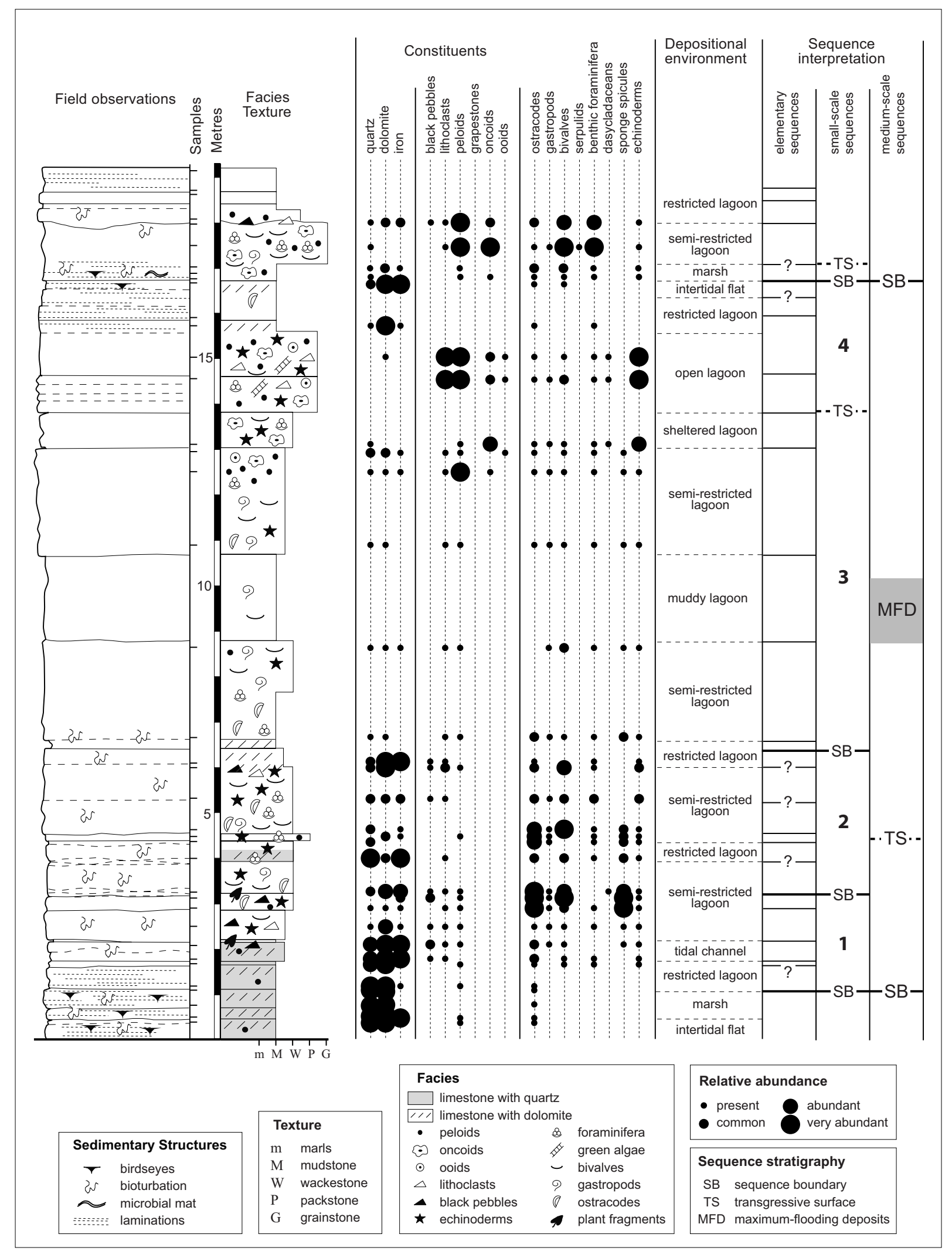

Fig. 3. Example of detailed facies analysis of a part of the Kimmeridgian in the Péry-Reuchenette section (compare with Fig. 10). Based on this analysis, depositional environments, high-resolution sequence stratigraphy and cyclostratigraphy are interpreted (modified from Colombié 2002). For discussion refer to text. 


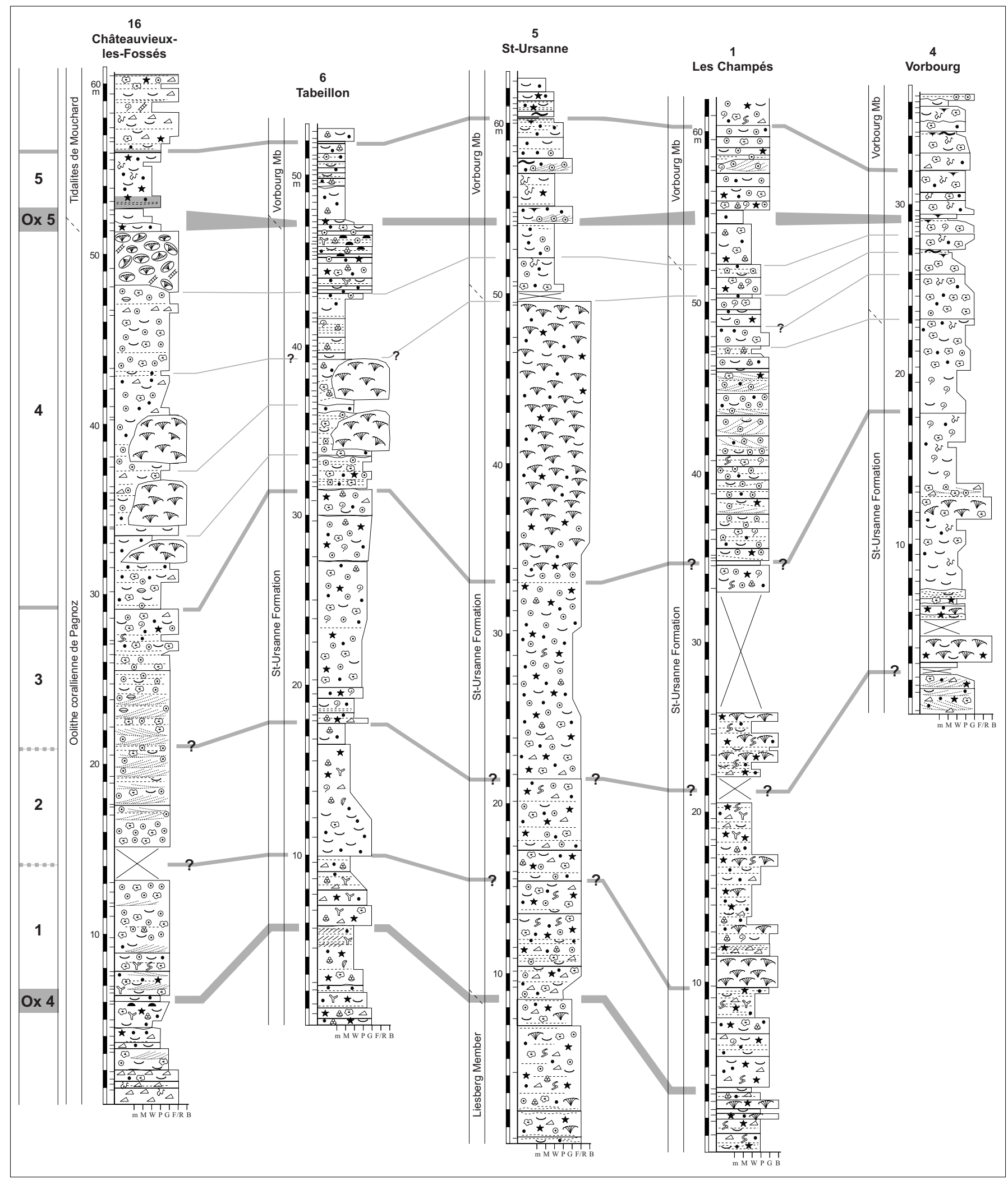

Fig. 4. Simplified logs of the interval between sequence boundaries Ox4 and Ox5. For discussion refer to text. Legend in Fig. 5. 


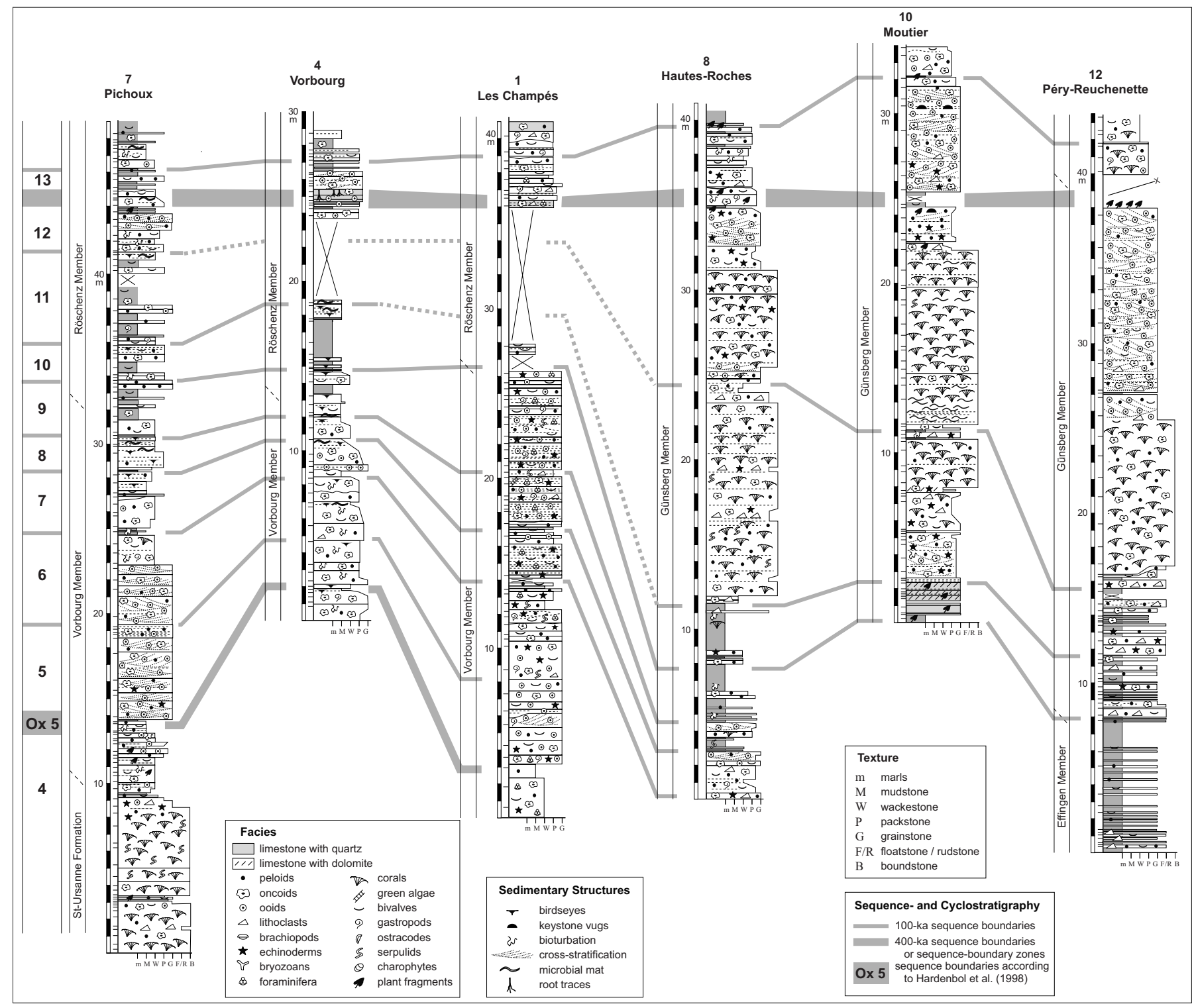

Fig. 5. Interval between sequence boundary Ox 5 and the important medium-scale sequence boundary at the top of small-scale sequence 12 . For discussion refer to text.

surface but by particularly thick beds and by the relatively most open-marine facies. In the basin, maximum flooding is expressed rather trough condensation and predominance of marls (Colombié 2002). All sections have been studied with the same detail as shown in Figure 3. However, for the purpose of this paper, only simplified versions are represented in Figures 4-12.

Once the best-fit correlation of all sections is established, the small-scale sequences (which are the best defined ones in the studied sections) are counted between ammonite zone boundaries and large-scale sequence boundaries. These boundaries have been dated by Hardenbol et al. (1998) through interpolation between the ages of the stage boundaries proposed by Gradstein et al. (1995). When dividing the duration of an interval by the corresponding number of smallscale sequences, the average duration of one small-scale sequence can be estimated.

\section{Sequence-stratigraphic interpretation}

In the following, a brief description of the key features is given, which are used for the identification of large-scale and small-scale sequences in Figures 4 to 12. The numbering of the small-scale sequences and the identification of medium- 


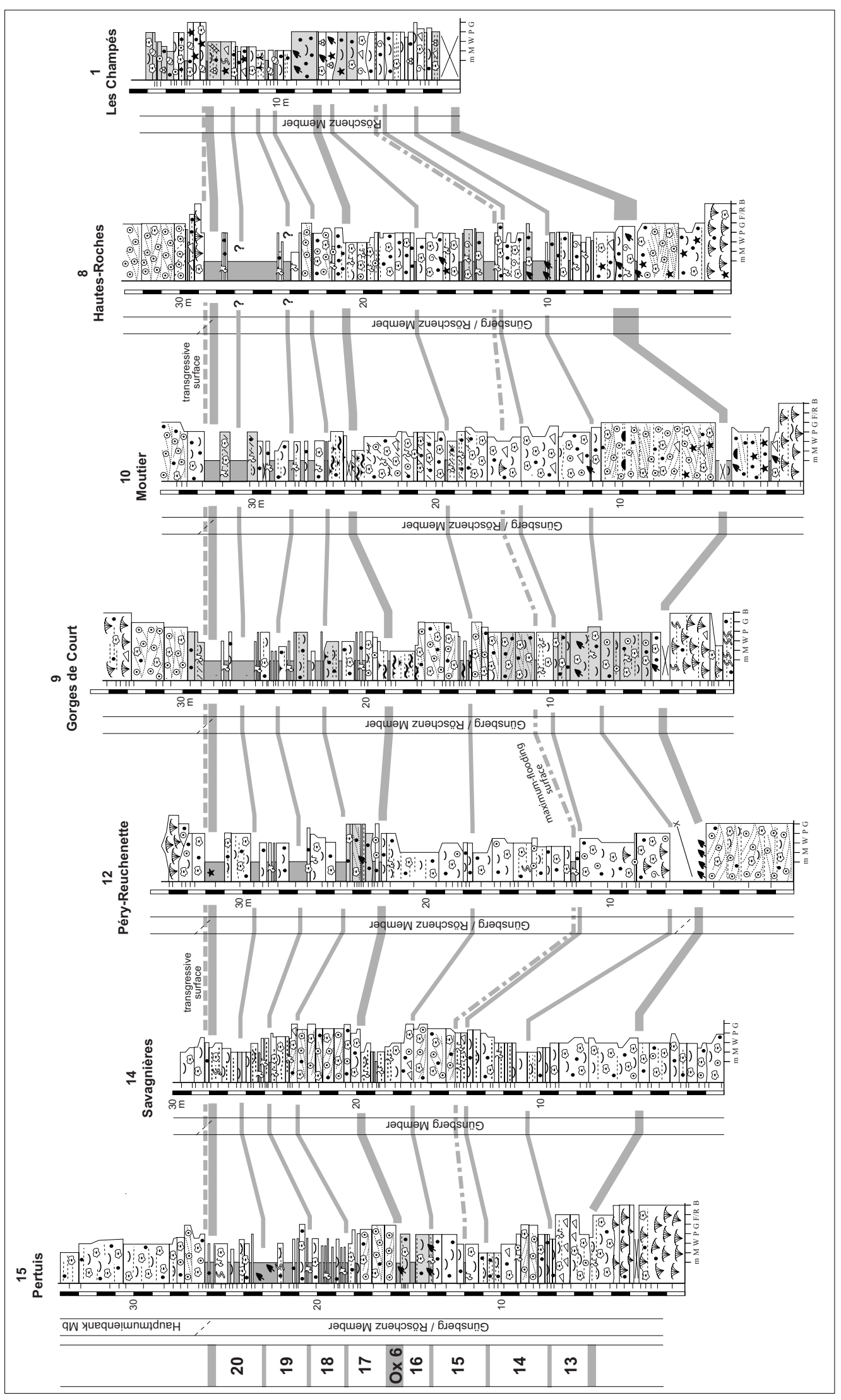

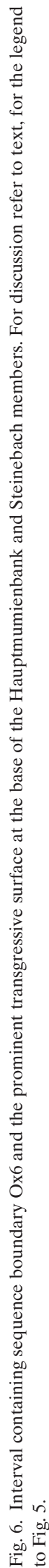


scale sequences is anticipated from the next chapter on cyclostratigraphy.

In the Swiss Jura, the transition from the Liesberg Member to the St-Ursanne Formation is marked by low-energy shallow-lagoonal facies and/or dolomitization interrupting generally high-energy deposits with ooids and corals (Fig. 4). This lithological limit lies in the Antecedens ammonite subzone (Gygi 1995) and corresponds to the large-scale sequence boundary Ox4 of Hardenbol et al. (1998). In the French Jura, at Châteauvieux-les-Fossés, the "Oolithe corallienne de Pagnoz" is considered the lateral equivalent of the St-Ursanne Formation (Enay et al. 1988). A conspicuous level with keystone vugs indicates a beach environment and is interpreted as representing sequence boundary Ox4. Above this sequence boundary, the sediments are dominated by ooids, oncoids and coral patch-reefs. No emersion features are present. In the high-energy facies it is therefore difficult to identify small-scale or elementary sequences because bedding surfaces may have formed through allocyclic as well as through autocyclic processes. Where there are changes to low-energy protected lagoons, however, an environmental change is suggested, which may be related to a drop of relative sea-level that isolated lagoons from the open ocean. At Tabeillon (metre 31.6), an erosion surface supports this interpretation. A massive reef installed itself at St-Ursanne, whereas two to three episodes of patch-reef growth are manifest at Tabeillon and Châteauvieuxles-Fossés. These episodes are interpreted as representing elementary sequences. Towards the top of the St-Ursanne Formation, keystone vugs, birdseyes and/or a change to low-energy facies herald a large-scale sequence boundary, which can be correlated with Ox5 (Gygi et al. 1998). At Châteauvieux-lesFossés, a thick bed of coral rubble testifies to the destruction of a reef, probably due to sea-level fall.

Large-scale sequence boundary $\mathrm{Ox} 5$ is also well represented in other sections of the Swiss Jura (Fig. 5). At Pichoux, for example, it overlies restricted lagoonal deposits with plant fragments. At Pichoux, Vorbourg and Les Champés, the Vorbourg Member represents high-energy ooid and oncoid facies, which pass upwards into marl-dominated deposits of the Röschenz Member. Birdseyes and microbial laminations are common, indicating periodically intertidal conditions. In the more southern sections (Hautes-Roches, Moutier, PéryReuchenette; Fig. 1), the Günsberg Member (Fig. 2A) features first siliciclastic-rich deposits, then coral reefs and ooid shoals. The Effingen Member at Péry-Reuchenette represents an epicontinental basin, which was gradually filled and covered by the prograding shallow-platform sediments (Gygi \& Persoz 1986). A barrier system composed of reefs and ooid shoals on the edge of the southward prograding platform (Günsberg Member) isolated the marly lagoon of the Röschenz Member to the north. Due to the well-developed facies contrasts and the commonly observed evolution from high-energy transgressive deposits to low-energy regressive facies capped by tidal flats, the identification of small-scale sequences is facilitated. The individual beds composing these small-scale sequences are considered as elementary sequences, which in many cases also exhibit tidal-flat caps. An interval exhibiting root traces at Vorbourg and plant fragments at Hautes Roches, Moutier and Péry-Reuchenette is considered as an important sequence boundary, which, however, has no equivalent in the chart of Hardenbol et al. (1998).

There is a general trend in the Günsberg and Röschenz members to become more marly and shallower towards the top (Fig. 6). Nevertheless, this evolution is periodically punctuated by ooid shoals and oncoid lagoons. Small-scale sequences can be identified relatively easily, and they are composed of 2 to 7 elementary sequences. A particularly strongly bioturbated horizon appearing in small-scale sequence 15 of several sections is interpreted as an important maximum-flooding surface. At Moutier, this level is represented by an exceptional occurrence of corals, testifying to the relatively most open-marine conditions. Plant fragments, tidal flats and dolomitization then point to an important large-scale sequence boundary, which lies approximately at the limit of the Bifurcatus and $\mathrm{Bi}$ mammatum ammonite zones (Gygi 1995) and can be considered as the equivalent of Ox6 (Fig. 2; Gygi et al. 1998). The rapid change to oncoid lagoons, ooid shoals and coral reefs (at Hautes-Roches) is interpreted as an important transgressive surface. Even at Les Champés, where lacustrine facies with charophytes are abundant, this transgression is marked by a pulse of high-energy deposits containing echinoderms.

This important transgressive surface defines the base of the Hauptmumienbank and Steinebach members (Fig. 2A). Oncoid-rich lagoonal facies characterise the Hauptmumienbank Member whereas the Steinebach Member is dominated by oolites and coral framestones (Fig. 7). Rapid vertical facies changes are common and help in the identification of smallscale sequences. The Oolithe rousse Member is a conspicuous level exhibiting reddish oolites containing detrital quartz and occasional plant fragments. It implies a long-term sea-level drop and also a climate change to more humid conditions, favouring increased input of iron. This member belongs to the Bimammatum ammonite zone (Gygi 1995) and is associated to large-scale sequence boundary Ox7 (Gygi et al. 1998). A marly interval rich in brachiopods above this boundary is interpreted as an important maximum flooding. Lagoonal facies with occasional coral patch-reefs dominate the overlying interval, at the top of which many sections exhibit dolomitization. At Les Champés, a prominent erosion surface occurs. This boundary lies at the limit between the Bimammatum and Planula ammonite zones (Gygi 1995) and is interpreted to correspond to large-scale sequence boundary Ox8 (Gygi et al. 1998).

Above sequence boundary $\mathrm{Ox} 8$, facies become more homogeneous and are dominated by the oolites that characterise the Verena Member (Fig. 8). Small-scale sequence boundaries are suggested by the presence of dolomite and evaporites. Limits of elementary sequences are locally indicated by dolomitized horizons, but in other cases are difficult to define in the high-energy facies. Black pebbles at Péry-Reuchenette 


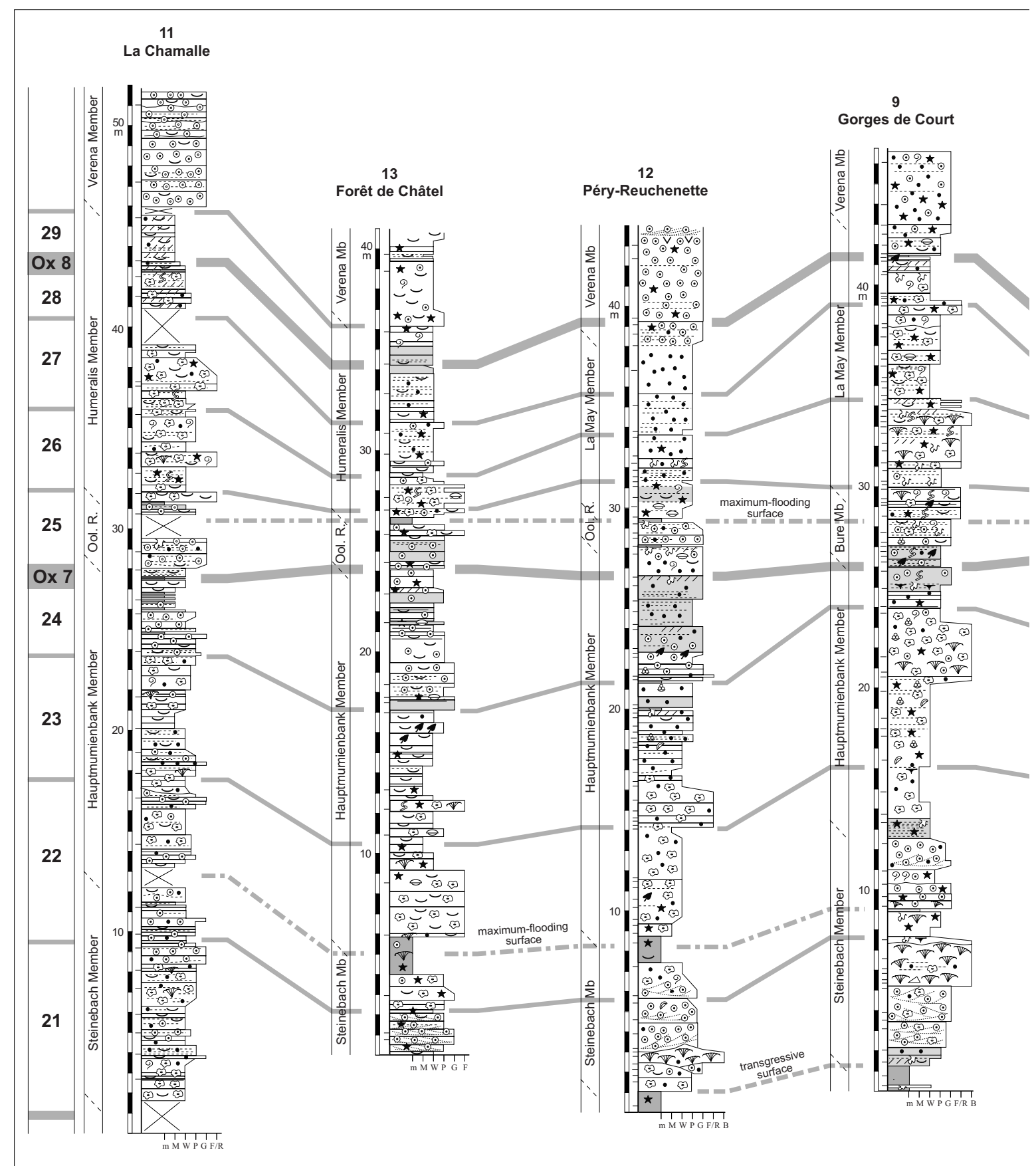

Fig. 7. Interval containing sequence boundaries Ox7 and Ox8. Note the prominent maximum-flooding surface within small-scale sequence 25 . For discussion refer to

and charophytes at Court imply a large-scale sequence boundary that is correlated with Kim1 of Hardenbol et al. (1998). The Oxfordian-Kimmeridgian boundary is not constrained by ammonites in these sections but is supposed to lie just below Kim1 (Fig. 2; Gygi et al. 1998).

The Reuchenette Formation (Fig. 2) is composed of mainly open-lagoonal facies, but dolomite caps and birdseyes point to periodic sea-level falls that induced small-scale sequence boundaries (Figs. 9 and 10). The platform sections are correlated with biostratigraphically well-dated hemipelagic sections in south-eastern France. There, large-scale sequence boundaries occur in intervals with relatively thick carbonate beds or with slumps (Colombié 2002). According to the biostratigraphy and the sequence-chronostratigraphic chart of Hardenbol et al. (1998), Kim1, Kim2, Kim3 and Kim4 can be identified and tentatively correlated with the most conspicuous emersion 


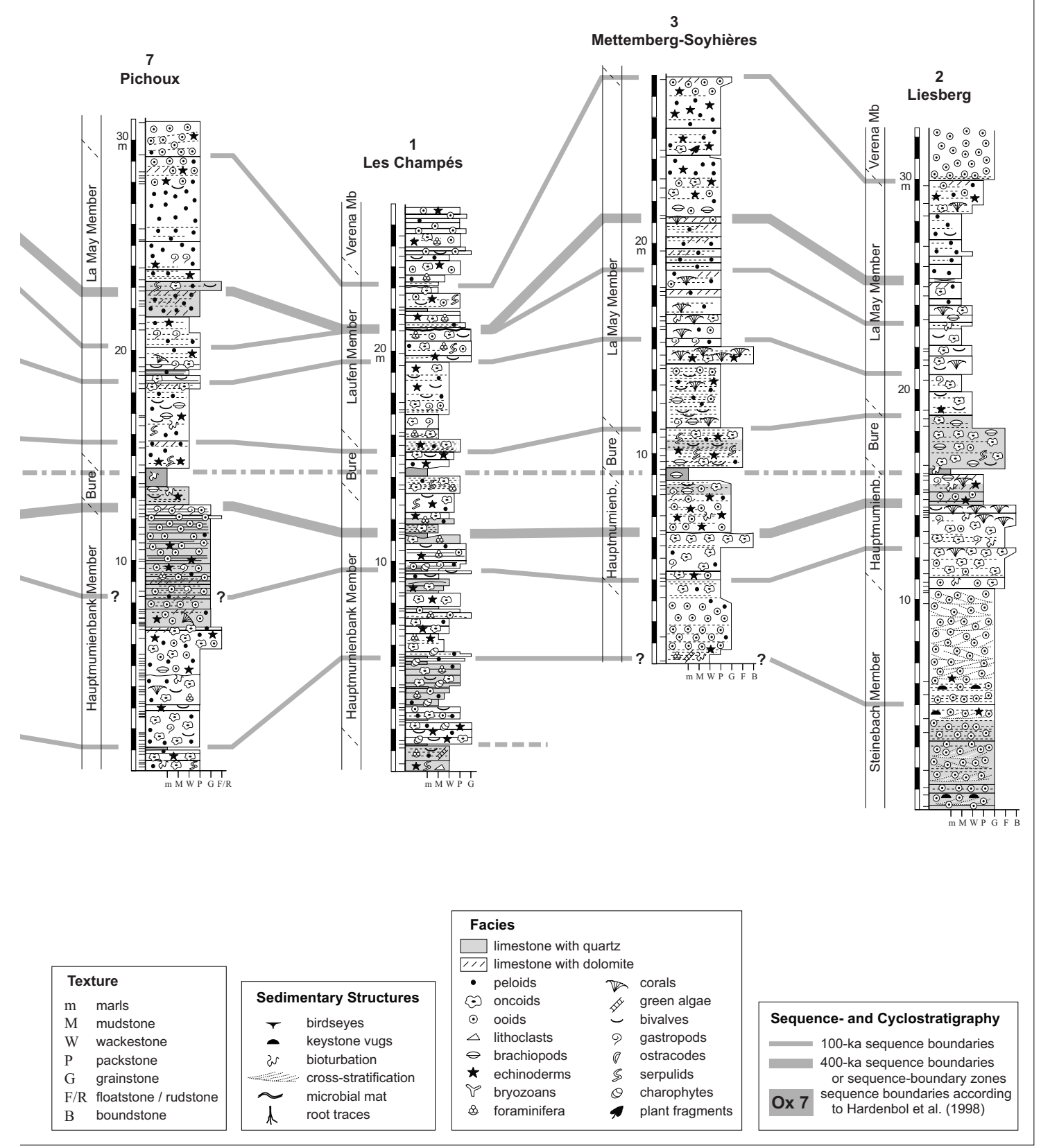

text.

horizons on the platform. For example, the base of the slump at Châteauneuf-d'Oze corresponds to the important sequence boundary displaying charophytes, birdseyes, dolomitization and black pebbles in the sections of the Swiss Jura (Kim2). The stacking pattern of the limestone-marl alternations in the hemipelagic sections does not permit a straightforward definition of small-scale sequences; their interpretation will be discussed when dealing with the cyclostratigraphy.
The Late Kimmeridgian in south-eastern France consists mainly of massive beds and is not suited for the definition of small-scale sequences and, consequently, for a cyclostratigraphic analysis. On the platform, however, the Reuchenette Formation continues with well-developed smallscale sequences, which locally display important dolomitized highstand deposits (especially in the Noirvaux section; Fig. 11). 


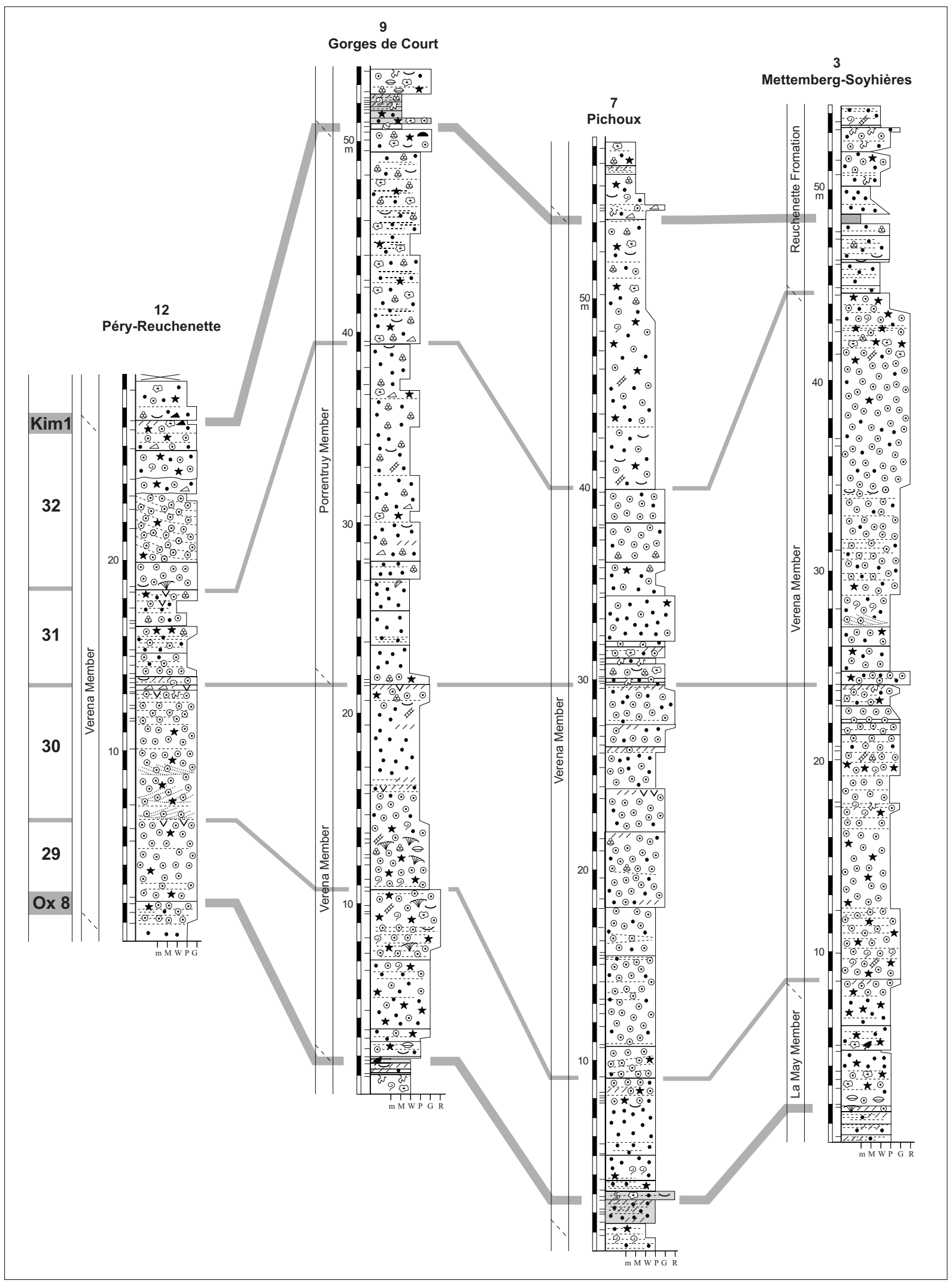

Fig. 8. Interval between sequence boundaries Ox8 and Kim1. For discussion refer to text, for the legend to Fig. 10. 
In many sections of the Swiss and French Jura, the Upper Virgula Marls mark the boundary between the Reuchenette and the Twannbach formations and correspond approximately to the Kimeridgian (sensu gallico) - Tithonian boundary (Fig. 2A). Below these marls, an important large-scale sequence boundary is implied by a prominent erosion surface at La Dôle, which correlates with birdseyes at Péry-Reuchenette and Pichoux (Fig. 12). The platform sections have been correlated to the hemipelagic section of Clue de Taulanne in south-eastern France (Rameil 2005). There, the marly interval at metres 32 to 34 is interpreted to be the equivalent of the Upper Virgula Marls. Sequence boundary Ti1 at Clue de Taulanne is indicated by an erosive surface overlain by a debris flow, while on the platform it is implied by tidal flats, black pebbles and important dolomitization. The Tithonian Twannbach Formation displays thin smallscale sequences dominated by shallow-lagoonal and tidal-flat facies. Dolomitization is common and can locally mask the depositional sequences (e.g., top of La Dôle section). In this case, the sequence-stratigraphic interpretation becomes speculative.

\section{Cyclostratigraphic interpretation}

In the studied sections, the small-scale sequences are relatively easy to define (example in Fig. 3) and can be correlated over the entire study area within the framework given by the biostratigraphy and the large-scale sequence boundaries. Between sequence boundary $\mathrm{Ox} 4$ in the Plicatilis zone (Middle Oxfordian) and Ti1 in the Hybonotum zone (earliest Tithonian), 68 small-scale sequences have been identified in the platform sections (Figs. 4-12). According to Hardenbol et al. (1998), the same interval lasted 7.4 million years (myr; Fig. 13). Assuming that each small-scale sequence has the same duration, it is implied that one small-scale sequence formed within approximately 108'800 years (108.8 kyr). As shown in Figure 3, each small-scale sequence contains on the average 5 elementary sequences. Considering all studied platform sections, this number varies between 2 and 7 but never lies outside this range. Furthermore, in many cases 4 small-scale sequences build up well-defined medium-scale sequences. Consequently, on the Jura platform, there is a clear hierarchical stacking of the different orders of depositional sequences.

In the hemipelagic sections, the limestone-marl couplets are considered as elementary sequences, i.e. they translate periodic changes in clay input, pelagic carbonate productivity and/or input of carbonate mud from the platform (Einsele \& Ricken 1991; Pittet et al. 2000). A clear stacking of these couplets into small- and medium-scale sequences, however, often is not visible (Figs. 9, 10, 12). In the biostratigraphically precisely dated Crussol section (Fig. 9; Atrops 1982), there are 52 to 78 limestone-marl couplets between the base of the Platynota and the top of the Divisum ammonite zones (52 if only the major couplets are counted, 78 if also the marl seams between limestone beds are considered). This interval covers about 1.4 myr according to Hardenbol et al. (1998), implying that one limestone-marl couplet formed within 17.9 to $26.9 \mathrm{kyr}$.
The durations for elementary, small-scale and mediumscale sequences thus obtained are close to those of the orbital periodicities (Milankovitch cycles). It is implied that elementary sequences correspond to the 20-kyr cycle of the precession of the equinoxes, small-scale sequences to the 100 -kyr short eccentricity cycle and medium-scale sequences to the 400-kyr long eccentricity cycle (Berger et al. 1989). Sequences corresponding to the 40-kyr obliquity cycle have not been identified unequivocally in the studied sections, although in some cases two elementary sequences appear to be grouped. Considering the large error margins of the radiometric dating of the stage boundaries (Fig. 13; Gradstein et al. 1995, 2004), the uncertainties in the interpolation to date the boundaries of ammonite zones and sequences (Hardenbol et al. 1998), the complexity of the atmospheric system through which the orbitally controlled insolation changes translate into climate, and the multiple feed-backs by which the climate translates into sea-level and environmental changes and finally into the sedimentary record, it is not astonishing that the values obtained in this study do not correspond exactly to the calculated orbital periodicities (Strasser et al. 1999).

Accepting the hypothesis that the observed hierarchical stacking of the sequences seen in the platform sections indeed corresponds to the record of orbital (Milankovitch) cycles, the interpretation of the sections can be fine-tuned. Where uncertainties exist in the placing of small-scale sequence boundaries, they are now put in a best-fit position taking into account the stacking of elementary sequences and the lateral correlation. On the other hand, the definition of elementary sequences is facilitated because - theoretically - there should be 5 contained in one small-scale sequence. If there are less than 5, it is implied that accommodation loss caused non-deposition or erosion of elementary sequences, or that sea-level change was not sufficient to create a facies contrast that was recorded as an elementary sequence ("missed beats"; Goldhammer et al. 1990). If there are more than 5 elementary sequences in a small-scale sequence, autocyclic processes were involved that created sequences independent of orbitally controlled sealevel changes. In the hemipelagic sections, small-scale sequences can be better identified when assuming that a limestone-marl couplet represents $20 \mathrm{kyr}$. It is seen that in many cases thicker limestone beds can be interpreted to be situated at the limits of small-scale sequences (assuming that lowstand deposits are dominated by more carbonate production and/or input; Colombié 2002; Colombié \& Strasser 2005).

Medium-scale sequences (corresponding to the 400-kyr long eccentricity cycle) are prominent on the platform (Figs. 4 -12). In the basinal sections, their boundaries are not clearly expressed but generally coincide with intervals of thick limestone beds and, in the case of Châteauneuf-d'Oze (Fig. 9), with a slump. In most cases, the large-scale sequence boundaries identified by Gygi et al. (1998) and Hardenbol et al. (1998) are also medium-scale sequence boundaries. This is thought to be due to the fact that orbitally controlled sea-level changes are superimposed on the long-term ( $2^{\text {nd }}$-order) sea-level trend. 


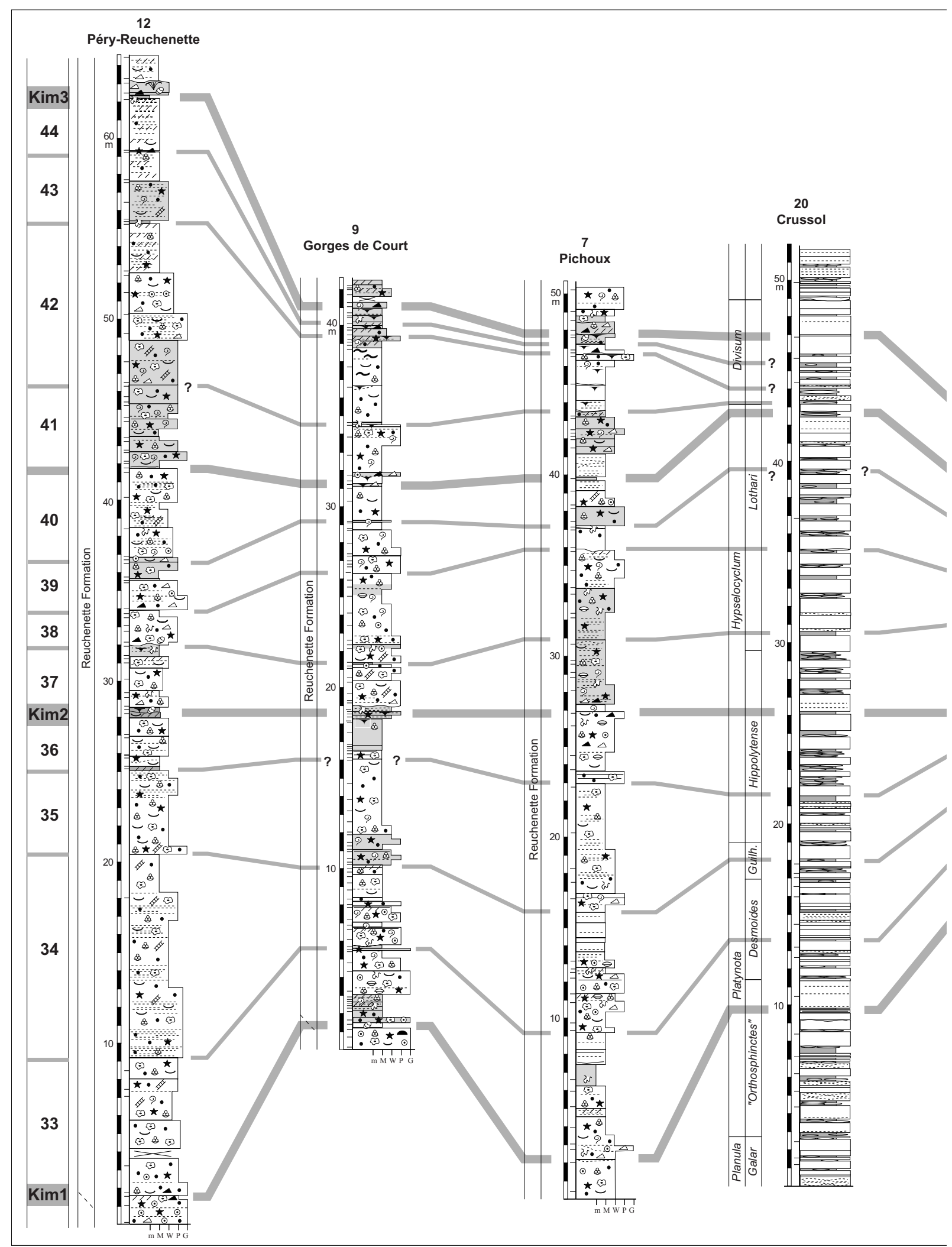

Fig. 9. Interval between sequence boundaries Kim1 and Kim3, with platform-to-basin correlation. For the basinal sections, ammonite zones and subzones are indicated. 


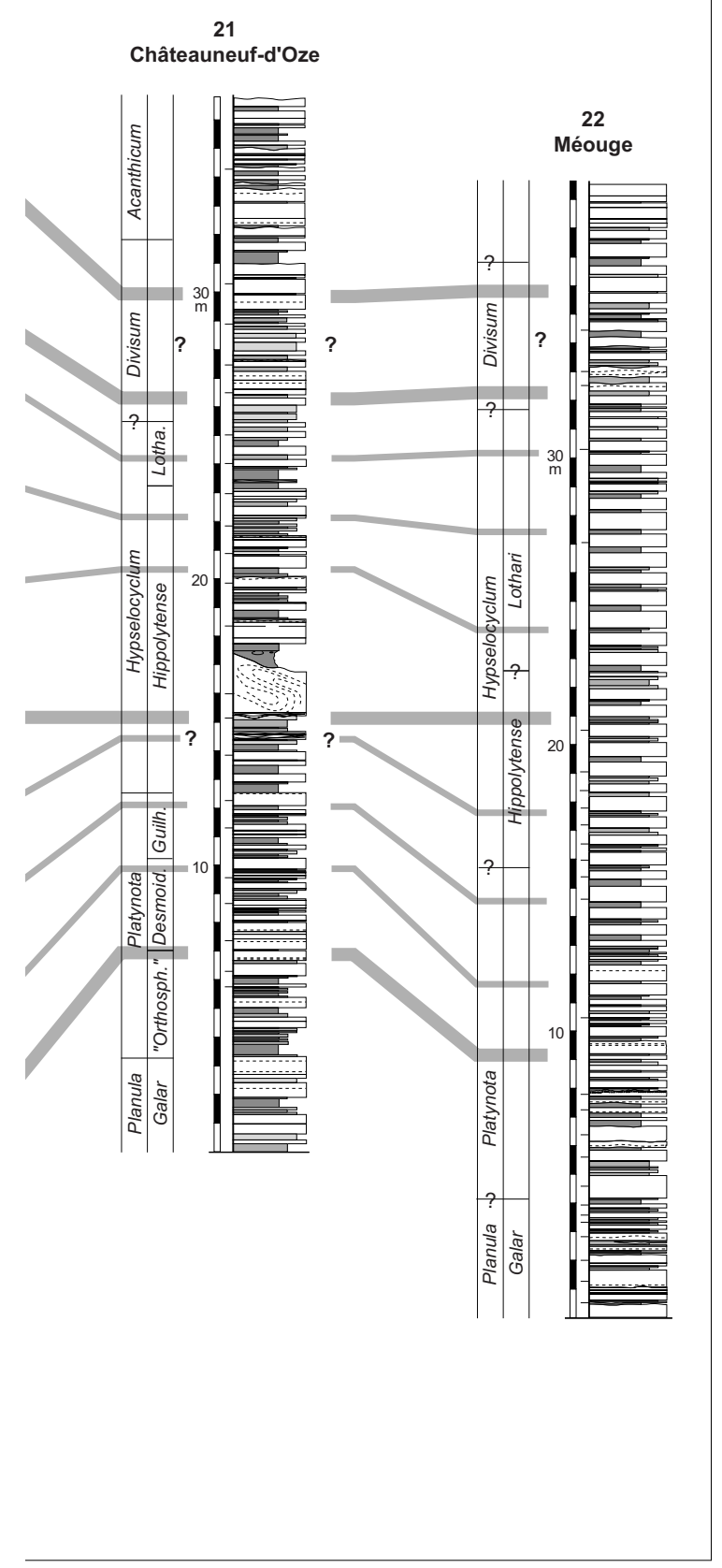

Depending on the basin configuration and on the amplitude of the sea-level drop, the 400-kyr cycles will produce features that are interpreted either as $3^{\text {rd }}$-order sequence boundaries or as more subtle boundaries that will not be labelled as such (Strasser et al. 2000).

In the present study, no time-series analyses based on accommodation changes or repetitive facies changes have been performed to confirm that the observed stacking of sequences corresponds to the hierarchy of orbital cycles (e.g., Weedon 2003). On the carbonate platform, bed thickness does not correspond to accommodation if sediment did not fill the available space (subtidal cycles; Osleger 1991), and rapid lateral and vertical facies changes preclude a simple pattern of facies evolution (Strasser \& Védrine 2007). Furthermore, bed thicknesses would have to be decompacted according to facies, and water depth would have to be estimated for each maximum flooding and each sequence boundary in order to reproduce a "true" sea-level curve as input for time-series analysis (Strasser et al. 2004). In the hemipelagic sections, high-resolution calcimetric and/or geochemical analyses would have to be performed in order to produce a representative time series that reflects cyclic environmental changes (Einsele \& Ricken 1991). These time-consuming procedures have not been undertaken for the present study. In the Méouge section, however, Boulila et al. (2006) have measured the magnetic susceptibility at high resolution and recognized Milankovitch cyclicity (20-, 40-, 100and 400-kyr cycles).

\section{Astronomical time scale}

For the Neogene, the astronomical time scale is tied to the Recent and allows tuning of the chronostratigraphic scales, better define GSSPs and intercalibrate radiometric dating methods (e.g., Hilgen et al. 2003; Kuiper et al. 2004). For the Oxfordian, Kimmeridgian and Tithonian, the stage boundaries are dated with error margins of 3 to 4 million years (Gradstein et al. 1995, 2004). However, the cyclostratigraphical approach demonstrated in this study allows establishing a floating astronomical time scale (Hilgen et al. 2004) with a time resolution of at least $100 \mathrm{kyr}$ (corresponding to one small-scale sequence). Where elementary sequences can be identified with confidence, the time resolution reaches $20 \mathrm{kyr}$. This permits a relatively precise evaluation of the durations of stages, largescale depositional sequences (Fig. 13) and ammonite zones (Fig. 14).

The duration of the Kimmeridgian (sensu gallico) thus is evaluated at 3.2 to 3.3 myr by cyclostratigraphy ( 32 small-scale sequences between Kim1 and Kim5, plus possibly one smallscale sequence between Kim5 and the Kimmeridgian-Tithonian boundary; see discussion below). Gradstein et al. (1995) give a value of 3.4 myr to this stage, Gradstein et al. (2004) 3.75 myr. The durations of large-scale ( $3^{\text {rd }}$-order) sequences

For discussion refer to text. Legend in Fig. 10. 


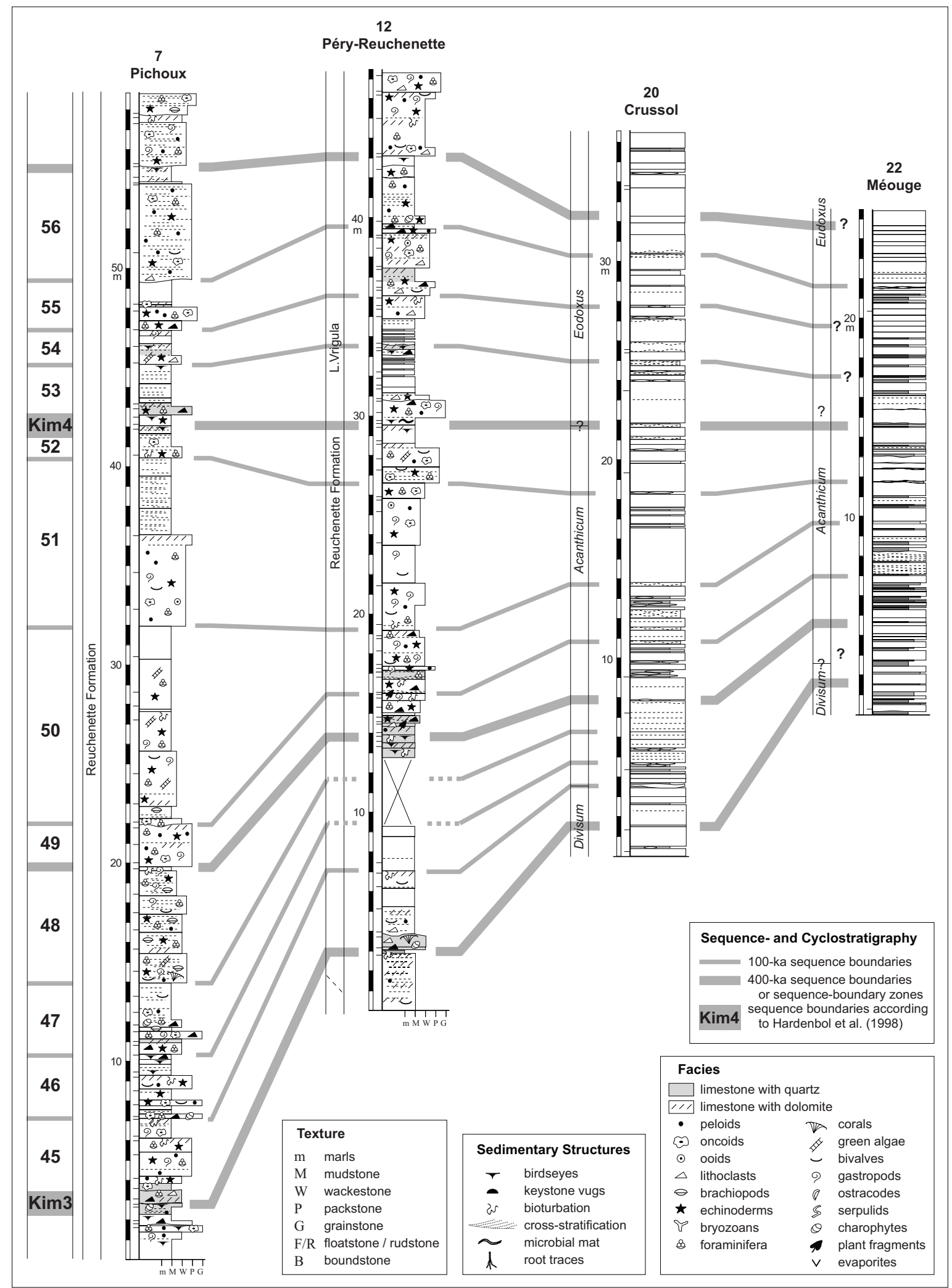

Fig. 10. Interval containing sequence boundary Kim4, with platform-to-basin correlation. For the basinal sections, ammonite zones are indicated. For discussion refer to text. 


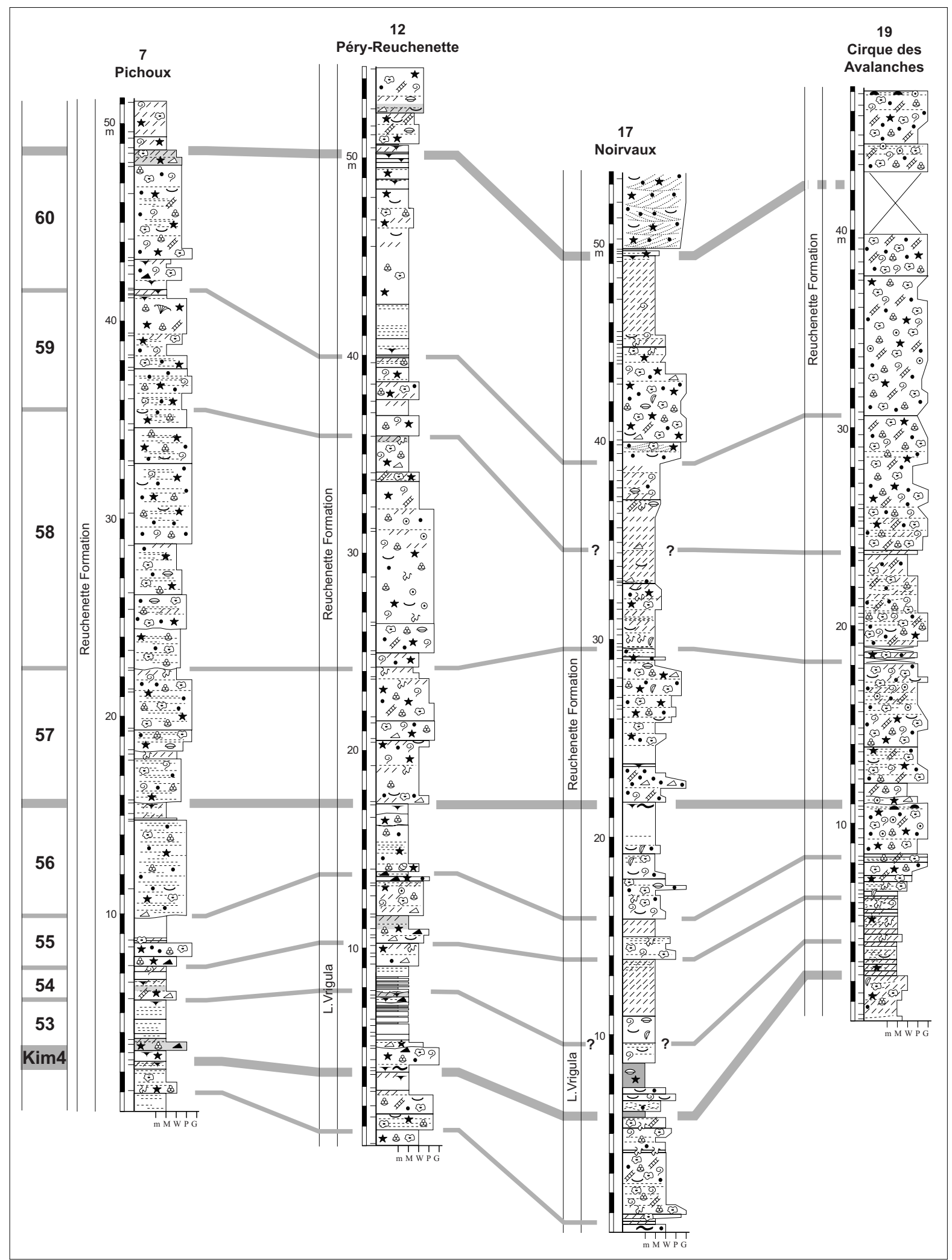

Fig. 11. Interval above sequence boundary Kim4. For discussion refer to text, for the legend to Fig. 10. 


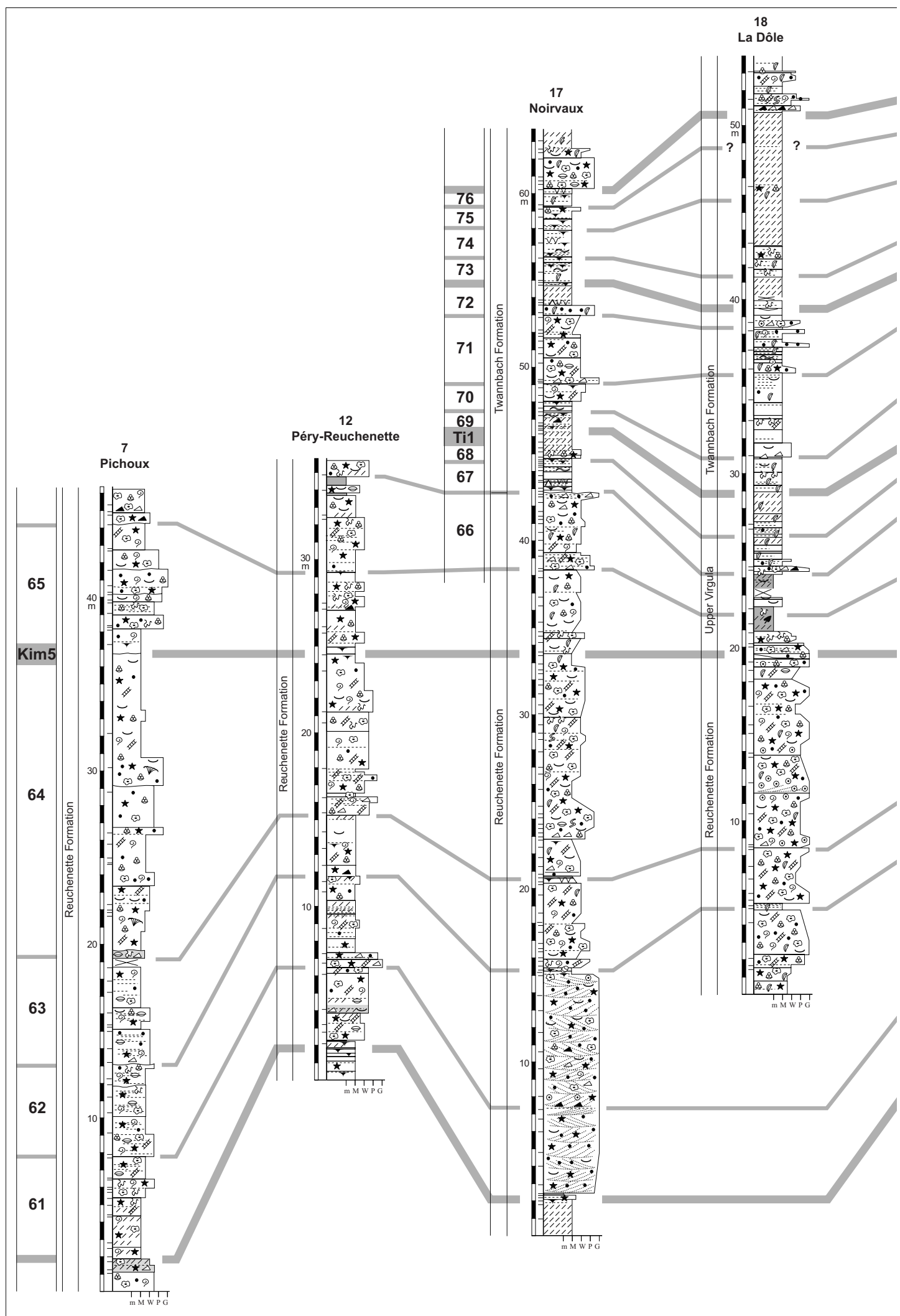

Fig. 12. Interval containing sequence boundaries Kim5 and Ti1, and correlation to a hemipelagic section. For the Clue de Taulanne section, ammonite zones are 


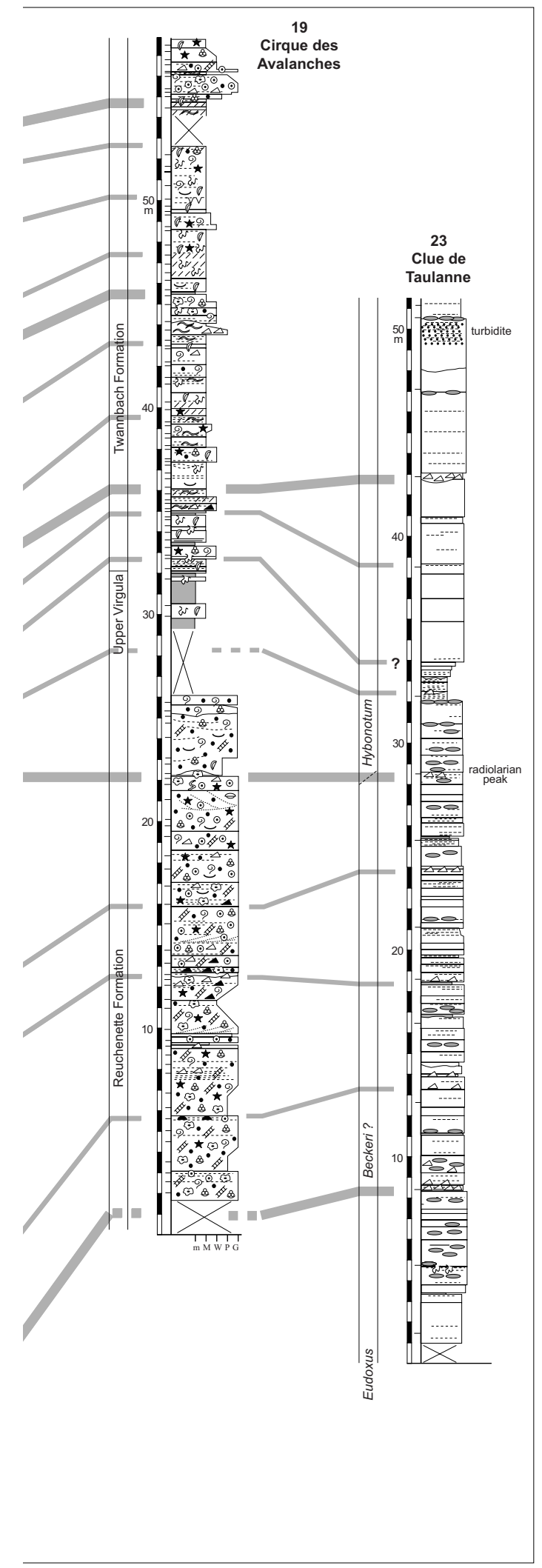

indicated. For discussion refer to text, for the legend to Fig. 10. are evaluated at $400 \mathrm{kyr}$ or multiples thereof (Fig. 13; Strasser et al. 2000), whereas the estimations of Hardenbol et al. (1998) are based on the interpolated ages of the sequence boundaries and may deviate considerably from our cyclostratigraphical interpretation (especially for the interval Kim5 - Ti1). In north-eastern Spain, Late Kimmeridgian ramp carbonates display characteristic stacking patterns. Spectral analysis of the bed thicknesses in one outcrop suggests that orbital cycles were involved (Bádenas et al. 2003) while elsewhere this control cannot be demonstrated with certainty (Aurell \& Bádenas 2004). For the interval between sequence boundaries Kim4 and Kim5, Bádenas et al. (2003) indicate $1.06 \mathrm{myr}$, while the study presented here suggests 1.2 myr (Fig. 13). Based on a platform-to-basin correlation in north-eastern Spain, Strasser et al. (2005) proposed a duration of 2.8 myr for the interval between $\mathrm{Ox} 4$ and $\mathrm{Ox} 8$, which is consistent with the value given in Figure 13.

The evaluation of the durations of ammonite zones is not straightforward (Fig. 14). Where only platform sections are available, the positions of the ammonite zone boundaries have been estimated based on the scheme of Gygi (1995; Fig. 2A). Also in the basinal sections the ammonite zone boundaries can not always be placed with precision (Atrops 1982). Some of the estimated durations are in good agreement with the values given by Hardenbol et al. (1998), others are quite different. For the Middle Oxfordian to Middle Kimmeridgian interval in southern Germany, Ruf et al. (2005) defined medium-scale (400-kyr) sequences based on a chemostratigraphic and palynofacies analysis of deeper ramp carbonates. The durations of the corresponding ammonite zones are in the same order as those defined in the present study (Fig. 14). Also in southern Germany, Pittet \& Strasser (1998b) counted 14 small-scale sequences within the Bimammatum ammonite zone, which would imply a duration of $1.4 \mathrm{myr}$ (versus $1.2 \mathrm{myr}$ in the present study). Weedon et al. (2004) established an astronomical time scale for the Kimmeridge Clay in southern England by spectral analysis of the variability of magnetic susceptibility, photoelectric factor and gamma ray. The resulting durations of ammonite zones, however, diverge considerably from the values presented here (Fig. 14). This may be at least partly due to problems with correlating ammonite zones between the Tethyan and the boreal realms (Colombié \& Rameil 2007).

\section{Discussion}

A prerequisite for establishing astronomical time scales of course is that all orbitally induced cycles are recorded in the sediment. In greenhouse periods such as during the Oxfordian and Kimmerdigian, cyclical climate changes translated into low-amplitude sea-level changes through waxing and waning of mountain glaciers and possibly also some small polar ice caps (Fairbridge 1976), through thermal expansion and retraction of the ocean surface water (Gornitz et al. 1982), through modifications in thermohaline oceanic circulations (Schulz \& Schäfer-Neth 1998) and/or through changes in water storage 


\begin{tabular}{|c|c|c|c|c|c|c|c|}
\hline \multicolumn{3}{|c|}{ Chronostratigraphy } & \multirow{3}{*}{$\begin{array}{c}\text { Biostratigraphy } \\
\text { Hybonotum }\end{array}$} & \multirow{2}{*}{$\begin{array}{c}\text { Sequence } \\
\text { boundaries } \\
\text { Ti } 1\end{array}$} & \multirow{2}{*}{$\begin{array}{c}\begin{array}{c}\text { Age of } \\
\text { sequence } \\
\text { boundaries }\end{array} \\
150.0 \\
\end{array}$} & \multirow{3}{*}{\begin{tabular}{|c|}
$\begin{array}{c}\text { Time between } \\
\text { sequence } \\
\text { boundaries (kyr) }\end{array}$ \\
\\
900 \\
\end{tabular}} & \multirow{3}{*}{\begin{tabular}{|c|}
$\begin{array}{c}\text { Number of small-scale } \\
\text { sequences between } \\
\text { sequence boundaries }\end{array}$ \\
4 \\
4
\end{tabular}} \\
\hline & Tithonian & $\frac{\lambda}{\frac{1}{\mathbb{N}}}$ & & & & & \\
\hline & $-150.7 \pm 3.0$ & & & \multirow{3}{*}{$\begin{array}{l}-\operatorname{Kim} 5- \\
-\operatorname{Kim} 4\end{array}$} & & & \\
\hline \multirow{5}{*}{ 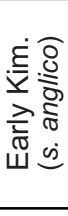 } & \multirow{5}{*}{$\begin{array}{l}\text { Kimmeridgian } \\
\quad \text { (s. gallico) }\end{array}$} & \multirow{3}{*}{ 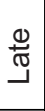 } & Beckeri & & \multirow{2}{*}{$\begin{array}{r}-150.9- \\
-152.0\end{array}$} & \multirow{2}{*}{1100} & \multirow{2}{*}{12} \\
\hline & & & Eudoxus & & & & \\
\hline & & & Acanthicum & Kim 3 & 1527 & 700 & 8 \\
\hline & & \multirow{2}{*}{$\begin{array}{l}\frac{\lambda}{\mathbb{C}} \\
\text { एँ }\end{array}$} & Divisum & Kim 2 & 1535 & 800 & 8 \\
\hline & & & $\begin{array}{l}\text { Rypselocyclum } \\
\text { Patynota }\end{array}$ & -Kim 1 & - 1540 & 500 & 4 \\
\hline & \multirow{6}{*}{ Oxfordian } & \multirow{4}{*}{ 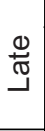 } & Planula & & -154. & 600 & 4 \\
\hline & & & \multirow[t]{2}{*}{ Bimammatum } & \multirow{3}{*}{$\begin{array}{l}-O \times 7 \\
-O \times 6\end{array}$} & $\begin{array}{r}134.0 \\
-1552 \\
\end{array}$ & 600 & 4 \\
\hline & & & & & & 600 & 8 \\
\hline & & & Bifurcatus & & 100.0 & \multirow{2}{*}{1200} & \multirow[t]{2}{*}{12} \\
\hline & & \multirow{2}{*}{$\begin{array}{l}\frac{0}{\overline{0}} \\
\frac{0}{2} \\
\Sigma\end{array}$} & Transversarium & \multirow{3}{*}{$\begin{array}{l}-O \times 5- \\
-O \times 4 \\
-O \times 3-\end{array}$} & -157.0 & & \\
\hline & & & Plicatilis & & $\begin{aligned}-15 \% \\
\end{aligned} 157$. & & \\
\hline & & & & & & & \\
\hline
\end{tabular}

Fig. 13. Duration of intervals between sequence boundaries as given in the sequence-chronostratigraphic chart of Hardenbol et al. (1998), and compared to the number of small-scale sequences implied from the cyclostratigraphic analysis. One small-scale sequence represents 100 kyr. For discussion refer to text.

in lakes and aquifers (Jacobs \& Sahagian 1993). On the shallow Jura platform, these sea-level fluctuations were recorded quite faithfully because relatively high subsidence rate (Wildi et al. 1989) created enough accommodation space. Emersion and non-deposition occurred mostly on the top of elementary sequences, and some small-scale sequences lack the topmost elementary sequence(s). The hierarchical stacking pattern, however, is not affected by this systematic, short-term lack of sedimentary record (Strasser et al. 1999). Differential subsidence was important on the Jura platform and caused the laterally variable thicknesses of the depositional sequences (Figs. 4 -12). Export of carbonate mud from the platform to the basin may also have been controlled by high-frequency, low-amplitude sea-level fluctuations (Pittet et al. 2000), thus at least partly governing the hemipelagic limestone-marl alternations. Clay input was probably controlled by a combination of sea-level changes and fluctuations of rainfall pattern in the hinterland from where the clays originated. Deep-water resediments are common especially in sections close to the slope. The irregular pattern of the limestone-marl alternations in the studied sections of south-eastern France demonstrates that the responsible processes were not simple. In the Kimmeridgian, an analysis has been attempted (Figs. 9, 10, and 12). Oxfordian hemipelagic sections of south-eastern France, however, have not been included in this work because it is often not clear if a limestone-marl couplet resulted from an episodic process or if it represents a "true" elementary sequence (e.g., at Château-neuf-d'Oze or at Vergons; Bombardiere \& Gorin 1998).

It is of advantage to include as many sections as possible in the cyclostratigraphic analysis: effects of autocyclic processes and of synsedimentary tectonics can thus be filtered out. Platform-to-basin correlations furnish an improved biostratigraph- ic frame because basinal sections are usually better dated. Furthermore, because platform systems and hemipelagic systems react differently to the same cyclical changes, a cross-check of the cyclostratigraphical interpretation becomes possible. In the present study it appears that elementary sequences are relatively well developed in the Kimmeridgian hemipelagic sections (limestone-marl couplets). On the platform, however, the small-scale sequences are easy to identify while the elementary sequences often are difficult to interpret.

Through the platform-to-basin correlation, two discrepancies are revealed. The first one concerns the medium-scale sequence boundary above small-scale sequence 40 (Fig. 9). In the well-dated Crussol section, the Hypselocyclum zone comprises 27 limestone-marl couplets, corresponding to $540 \mathrm{kyr}$. The duration of this zone is estimated at $620 \mathrm{kyr}$ by Hardenbol et al. (1998). At Méouge, which was chemostratigraphically correlated with Crussol by De Rafélis (2000), this interval also contains 27 limestone-marl couplets. At Châteauneuf-d'Oze, however, only 17 couplets are counted (including the slump), and the Lothari subzone appears reduced. It is well possible that a medium-scale sea-level drop caused erosion and/or nondeposition at Châteauneuf-d'Oze, although no traces of this are visible in the field. At Crussol and Méouge, however, irregular beds at the base of the Divisum zone may testify to such an event. The number of limestone-marl couplets within the Divisum zone varies between 10 and 12, but the duration of this zone is estimated at $610 \mathrm{kyr}$ by Hardenbol et al. (1998). The correlation to the platform sections suggests that the same interval contains about 4 small-scale sequences, which would correspond to $400 \mathrm{kyr}$. More well-dated sections should be studied to resolve this mismatch.

The second discrepancy appears around sequence boundary Kim5 (Fig. 12). According to Hardenbol et al. (1998), this 


\begin{tabular}{|c|c|c|c|c|c|}
\hline \multirow{2}{*}{$\begin{array}{l}\text { Ammonite zones } \\
\text { (Tethyan) }\end{array}$} & \multicolumn{4}{|c|}{ Duration in kyr according to } & \multirow{2}{*}{$\begin{array}{c}\text { Ammonite zones } \\
\text { (boreal) }\end{array}$} \\
\hline & Hardenbol et al. (1998) & Ruf et al. (2005) & this work & Weedon et al. (2004) & \\
\hline Hybonotum & 1400 & & & $>243$ & Elegans \\
\hline Beckeri & 670 & & & $>1062$ & Autissiodorensis \\
\hline Eudoxus & 740 & & $\sim 800 ?$ & $>1486$ & Eudoxus \\
\hline Acanthicum & 520 & $\sim 600$ & $\sim 700$ & $>745$ & Mutabilis \\
\hline Divisum & 610 & $\sim 800$ & 400 & \multirow{2}{*}{$>287$} & \multirow{2}{*}{ Cymodoce } \\
\hline Hypselocyclum & 620 & $\sim 500$ & 540 & & \\
\hline Platynota & 250 & $\sim 300$ & $\sim 400$ & $>290$ & Baylei \\
\hline Planula & 530 & $\sim 600$ & $300-400$ & & \\
\hline Bimammatum & 1050 & $\sim 1000$ & $\sim 1200$ & & \\
\hline Bifurcatus & 520 & $\sim 500$ & $700-800$ & & \\
\hline Transversarium & 1060 & & $500-700$ & & \\
\hline
\end{tabular}

Fig. 14. Duration of ammonite zones according to different authors and compared with the present study. Correlation of Tethyan and boreal ammonite zones based on Hardenbol et al. (1998). For discussion see text.

boundary is situated in the Autissiodorensis ammonite zone (Fig. 2). However, if the correlation proposed in Fig. 12 and the dating is correct, Kim5 would be situated at the very base of the Hybonotum ammonite zone (which at Clue de Taulanne is implied by a peak in radiolarian abundance; Rameil 2005). Consequently, the Upper Virgula Marls would rather belong to the base of the Tithonian than to the top of the Kimmeridgian (Fig. 2). Kim5 would then correspond to the Kimmeridgian-Tithonian boundary. Again, more sequence- and biostratigraphic studies are needed to clarify this issue.

\section{Conclusions}

Through detailed facies analysis and the interpretation of the evolution of depositional environments through space and time it can be shown that Oxfordian and Kimmeridgian platform and basin carbonates hold a record of orbital (Milankovitch) cycles. The cycles of the precession of the equinoxes and of short and long eccentricity controlled sea-level changes that caused the formation of hierarchically stacked depositional sequences. The general biostratigraphic and sequence-chronostratigraphic framework of the studied sections furnishes a rough timing, which confirms that the durations of the depositional sequences indeed correspond to the expected orbital frequencies. It is thus implied that the observed elementary sequences formed within $20 \mathrm{kyr}$, whereas the smalland medium-scale sequences correspond to 100 and $400 \mathrm{kyr}$, respectively. Through lateral correlation of the sequences between the platform sections and from platform to basin, local and autocyclic factors are eliminated and a high-resolution time frame is established.
However, Figures 13 and 14 reveal some important discrepancies in the estimation of the duration of sequences and biozones depending on the applied method (interpolation between radiometric ages, different cyclostratigraphical approaches). Consequently, more effort has to be invested in the precise biostratigraphical positioning of sections and in the careful analysis of depositional sequences. The more sections are analysed in different depositional settings and correlated, the better the allocyclic control on deposition can be evaluated and used for establishing an astronomical time scale.

The precise timing of depositional sequences allows for a very detailed interpretation of the evolution of depositional environments. The time resolution approaches that of the Pleistocene and Holocene where the controlling parameters are much better known than in the deep geologic past. Consequently, sedimentation rates, speeds of ecological and evolutionary changes, or the timing of porosity development in reservoir rocks can be evaluated with unprecedented resolution. From the correlation of the platform sections it also becomes evident that lateral facies changes within small-scale (and, where identifiable, within elementary) sequences are common and imply a highly structured carbonate platform where several depositional environments were juxtaposed (Strasser \& Védrine 2007).

Any geological time scale is not a research goal by itself but serves as a base for the analysis of geological processes. Therefore, the here presented astronomical time scale is seen as a starting point for future research. It is hoped that it will be useful to better constrain the timing of ecological, sedimentological and diagenetic processes that governed the Jura platform during Oxfordian and Kimmeridgian times. 


\section{Acknowledgements}

I am indebted to Virginie Bard, Thomas Bühler, Claude Colombié, Christophe Dupraz, Philippe Gsponer, Wolfgang Hug, Philippe Jordan, Daniel Oswald Bernard Pittet, Niels Rameil and Gaëtan Rauber who logged and sampled the sections conscientiously and analysed the facies in much detail. Without their work this synthesis would not have been possible. I also thank the reviewers Bruno D'Argenio and Pierre-Yves Collin for their constructive remarks, and the guest editors Helmut Weissert and Hanspeter Funk for the careful editing. The financial support of the Swiss National Science Foundation is gratefully acknowledged (Projects No. 20-67736.02 and 109214.05). This paper is dedicated to Rudolf Trümpy who has initiated me to the science of stratigraphy.

\section{REFERENCES}

Allenbach, R.P. 2001: Synsedimentary tectonics in an epicontinental sea: a new interpretation of the Oxfordian basins of northern Switzerland. Eclogae Geologicae Helvetiae 94, 265-287.

Aurell, M. \& Bádenas, B. 2004: Facies and depositional sequence evolution controlled by high-frequency sea-level changes in a shallow-water carbonate ramp (late Kimmeridgian, NE Spain). Geological Magazine 141, $717-733$.

Atrops, F. 1982: La sous-famille des Ataxioceratinae (Ammonitina) dans le Kimméridgien inférieur du Sud-Est de la France. Systématique, évolution, chronostratigraphie des genres Orthosphinctes et Ataxioceras. Document du Laboratoire de Géologie de Lyon 83, 463 pp.

Bádenas, B., Aurell, M., Rodriguez-Tovar, F.J. \& Pardo-Igúzquiza, E. 2003: Sequence stratigraphy and bedding rhythms of an outer ramp limestone succession (Late Kimmeridgian, Northeast Spain). Sedimentary Geology 161, 153-174.

Bard, V. 1999: Géologie de la région de Vuillafans (Doubs, France). Unpublished Diploma Thesis, University of Fribourg, $87 \mathrm{pp}$.

Berger, A., Loutre, M.F. \& Dehant, V. 1989: Astronomical frequencies for pre-Quaternary palaeoclimate studies. Terra Nova 1, 474-479.

Bolliger, W. \& Burri, P. 1970: Sedimentologie von Schelf-Carbonaten und Beckenablagerungen im Oxfordien des zentralen Schweizer Jura. Beiträge zur geologischen Karte der Schweiz (N.F.) 140, 96 pp.

Bombardiere, L. \& Gorin, G. 1998: Sedimentary organic matter in condensed sections from distal oxic environments: examples from the Mesozoic of SE France. Sedimentology 45, 771-788.

Boulila, S., Galbrun, B., Collin, P.-Y. \& Schnyder, J. 2006: High-resolution cyclostratigraphic analysis of magnetic susceptibility record from a Kimmeridgian alternating marl-limestone succession (La Méouge, Vocontian Basin, France). Abstract $7^{\text {th }}$ International Congress on Jurassic System, Jurassica 4, 149.

Bühler, T. 1997: Géologie de la région de la Combe Tabeillon (Sud-Ouest de Glovelier), avec une analyse séquentielle d'une coupe de l'Oxfordien moyen (Formation de St-Ursanne). Unpublished Diploma Thesis, University of Fribourg, 79 pp.

Clari, P.A., Dela Pierre, F. \& Martire, L. 1995: Discontinuities in carbonate successions: identification, interpretation and classification of some Italian examples. Sedimentary Geology 100, 97-121.

Colombié, C. 2002: Sédimentologie, stratigraphie séquentielle et cyclostratigraphie du Kimméridgien du Jura suisse et du Bassin vocontien (France): relations plate-forme - bassin et facteurs déterminants. GeoFocus 4, Fribourg, 198 pp.

Colombié, C. \& Rameil, N. 2007: Tethyan-to-boreal correlation in the Kimmeridgian using high-resolution sequence stratigraphy (Vocontian Basin, Swiss Jura, Boulonnais, Dorset). International Journal of Earth Sciences 96, 567-591

Colombié, C. \& Strasser, A. 2005: Facies, cycles, and controls on the evolution of a keep-up carbonate platform (Kimmeridgian, Swiss Jura). Sedimentology 52, 1207-1227.

D’Argenio, B., Fischer, A.G., Premoli Silva, I., Weissert H. \& Ferreri V. (Eds.)(2004): Cyclostratigraphy: approaches and case histories. SEPM Special Publication 81, 311 pp.
De Rafélis, M., Emmanuel, L., Renard, M., Atrops, F. \& Jan du Chene, R. 2000: Geochemical characterisation (Mn content) of third order eustatic sequences in Upper Jurassic pelagic carbonates of the Vocontian Trough (SE France). Eclogae Geologicae Helvetiae 94, 145-152.

Dercourt, J., Ricou, L.E. \& Vrielynck, B. 1993: Atlas: Tethys palaeogeographic maps. CCGM, Paris.

Dunham, R.J. 1962: Classification of carbonate rocks according to depositional texture. AAPG Memoir 1, 108-121.

Dupraz, C. 1999: Paléontologie, paléoecologie et évolution des faciès récifaux de l'Oxfordien Moyen-Supérieur (Jura suisse et français). GeoFocus 2, Fribourg, 247 pp.

Einsele, G. Ricken, W. 1991: Limestone-marl alternation - an overview. In: Einsele, G., Ricken, W. \& Seilacher A. (Eds.): Cycles and Events in Stratigraphy. Springer, Heidelberg, 23-47.

Enay, R., Contini, D. \& Boullier, A. 1988: Le Séquanien-type de FrancheComté (Oxfordien supérieur): datations et corrélations nouvelles, conséquences sur la paléogéographie et l'évolution du Jura et régions voisines. Eclogae Geologicae Helvetiae 81, 295-363.

Fairbridge, R.W. 1976: Convergence of evidence on climatic change and ice ages. Annals of the New York Academy of Sciences 91, 542-579.

Fischer, A.G., D’Argenio, B., Premoli Silva, I., Weissert, H. \& Ferreri, V. 2004: Cyclostratigraphic approach to Earth's history: an introduction. SEPM Special Publication 81, 5-13.

Goldhammer, R.K., Dunn, P.A., \& Hardie, L.A. 1990: Depositional cycles, composite sea-level changes, cycle stacking patterns, and the hierarchy of stratigraphic forcing: examples from Alpine Triassic platform carbonates. Geological Society of America Bulletin 102, 535-562.

Gornitz, V., Lebedeff, S. \& Hansen, J. 1982: Global sea-level trend in the past century. Science 215, 1611-1614.

Gradstein, F.M., Agterberg, F.P., Ogg, J.G., Hardenbol, J., van Veen, P., Thierry, J. \& Huang, Z. 1995: A Triassic, Jurassic and Cretaceous time scale. SEPM Special Publication 54, 95-126.

Gradstein, F., Ogg, J. \& Smith, A. 2004: A geologic time scale 2004. Cambridge University Press, Cambridge, 589 pp.

Gsponer, P. 1999: Etude géologique et sédimentologique de l'anticlinal du Chasseral dans le région de La Heutte. Unpublished Diploma Thesis, University of Fribourg, $107 \mathrm{pp}$.

Gygi, R.A. 1995: Datierung von Seichtwassersedimenten des Späten Jura in der Nordwestschweiz mit Ammoniten. Eclogae Geologicae Helvetiae 88, $1-58$.

Gygi, R.A. 2000: Integrated stratigraphy of the Oxfordian and Kimmeridgian (Late Jurassic) in northern Switzerland and adjacent southern Germany. Memoir of the Swiss Academy of Sciences 104, 152 pp.

Gygi, R.A. \& Persoz, F. 1986 : Mineralostratigraphy, litho- and biostratigraphy combined in correlation of the Oxfordian (Late Jurassic) formations of the Swiss Jura range. Eclogae Geologicae Helvetiae 79, 385-454.

Gygi, R.A., Coe, A.L. \& Vail, P.R. 1998: Sequence stratigraphy of the Oxfordian and Kimmeridgian stages (Late Jurassic) in northern Switzerland. SEPM Special Publication 60, 527-544.

Hardenbol, J., Thierry, J., Farley, M.B., Jacquin, T., De Graciansky, P.-C. \& Vail, P.R. 1998: Jurassic sequence chronostratigraphy. SEPM Special Publication 60 , chart.

Heer, O. 1865: Die Urwelt der Schweiz. Schulthess, Zurich, 622 pp.

Hilgen, F.J., Abdul Aziz, H., Krijgsman, W., Raffi, I. \& Turco, E. 2003: Integrated stratigraphy and astronomical tuning of the Serravallian and lower Tortonian at Monte dei Corvi (Middle-Upper Miocene, northern Italy). Palaeogeography, Palaeoclimatology, Palaeoecology 199, 229-264.

Hilgen, F.J., Schwarzacher, W. \& Strasser, A. 2004: Concepts and definitions in cyclostratigraphy (second report of the cyclostratigraphy working group). SEPM Special Publication 81, 303-305.

Hillgärtner, H. 1998: Discontinuity surfaces on a shallow-marine carbonate platform (Berriasian - Valanginian, France and Switzerland). Journal of Sedimentary Research 68, 1093-1108.

Hug, W. 2003: Sequenzielle Faziesentwicklung der Karbonatplattform des Schweizer Jura im Späten Oxford und frühesten Kimmeridge. GeoFocus 7, Fribourg, 156 pp.

Jacobs, D.K. \& Sahagian, D.L. 1993: Climate-induced fluctuations in sea level during non-glacial times. Nature 361, 710-712. 
Jank, M. 2004: New insights into the development of the Late Jurassic Reuchenette Formation of NW Switzerland (Late Oxfordian to Late Kimmeridgian, Jura Mountains). Unpublished PhD Thesis University of Basel, 121 pp.

Jank, M., Wetzel, A. \& Meyer, C.A. 2006: Late Jurassic sea-level fluctuations in NW Switzerland (Late Oxfordian to Late Kimmeridgian): closing the gap between the Boreal and Tethyan realm in Western Europe. Facies $52,487-519$.

Jordan, P. 1999: Géologie de la région de Montoz (Jura bernois) avec analyse séquentielle de deux profiles de l'Oxfordien moyen et supérieur. Unpublished Diploma Thesis, University of Fribourg, 104 pp.

Kuiper, K.F., Hilgen, F.J., Steenbrink, J. \& Wijbrans, J.R. 2004: ${ }^{40} \mathrm{Ar} /{ }^{39} \mathrm{Ar}$ ages of tephras intercalated in astronomically tuned Neogene sedimentary sequences in the eastern Mediterranean. Earth and Planetary Science Letters 222, 583-597.

Montañez, I.A. \& Osleger, D.A. 1993: Parasequence stacking patterns, thirdorder accommodation events, and sequence stratigraphy of Middle to Upper Cambrian platform carbonates, Bonanza King Formation, southern Great Basin. AAPG Memoir 57, 305-326.

Mouchet, P.O.J. 1998: Stratigraphy and mineralostratigraphy of the Kimmeridgian in the central Jura mountains of Switzerland and eastern France. Eclogae Geologicae Helvetiae 91, 53-68.

Osleger, D. 1991: Subtidal carbonate cycles: implications for allocyclic vs. autocyclic controls. Geology 19, 917-920.

Oswald, D. 1998: Géologie de la région de St-Ursanne (Jura). Unpublished Diploma Thesis, University of Fribourg, 82 pp.

Pittet, B. 1996: Contrôles climatiques, eustatiques et tectoniques sur des systèmes mixtes carbonates-siliciclastiques de plate-forme: exemples de l'Oxfordien (Jura suisse, Normandie, Espagne). Unpublished PhD Thesis, University of Fribourg, 258 pp.

Pittet, B. \& Strasser, A. 1998a: Long-distance correlations by sequence stratigraphy and cyclostratigraphy: examples and implications (Oxfordian from the Swiss Jura, Spain, and Normandy). Geologische Rundschau 86, 852-874.

Pittet, B. \& Strasser, A. 1998b: Depositional sequences in deep-shelf environments formed through carbonate-mud import from the shallow platform (Late Oxfordian, German Swabian Alb and eastern Swiss Jura). Eclogae Geologicae Helvetiae 91, 149-169.

Pittet, B., Strasser, A. \& Mattioli, E. 2000: Depositional sequences in deepshelf environments: a response to sea-level changes and shallow-platform carbonate productivity (Oxfordian, Germany and Spain). Journal of Sedimentary Research 70, 392-407.

Rameil, N. 2005: Carbonate sedimentology, sequence stratigraphy, and cyclostratigraphy of the Tithonian in the Swiss and French Jura Mountains. GeoFocus 13, Fribourg, 246 pp.

Rauber, G. 2001: Géologie de la région de Bärschwil-Grindel (Jura soleurois, Suisse) avec analyse détaillée dans l'Oxfordien supérieur. Unpublished Diploma Thesis, University of Fribourg, $94 \mathrm{pp}$.

Ruf, M., Link, E., Pross, J. \& Aigner, T. 2005: A multi-proxy study of deeperwater carbonates (Upper Jurassic, southern Germany): combining sedimentology, chemostratigraphy and palynofacies. Facies 51, 339-362.

Schulz, M. \& Schäfer-Neth, C. 1998: Translating Milankovitch climate forcing into eustatic fluctuations via thermal deep water expansion: a conceptual link. Terra Nova 9, 228-231.
Strasser, A. 1991: Lagoonal-peritidal sequences in carbonate environments: autocyclic and allocyclic processes. In: Einsele, G., Ricken, W. \& Seilacher A. (Eds.): Cycles and Events in Stratigraphy. Springer, Heidelberg, 709-721.

Strasser, A., Aurell, M., Bádenas, B., Meléndez, G. \& Tomás, S. 2005: From platform to basin to swell: orbital control on sedimentary sequences in the Oxfordian, Spain. Terra Nova 17, 407-413.

Strasser, A. \& Davaud, E. 1983: Black pebbles of the Purbeckian (Swiss and French Jura). Eclogae Geologicae Helvetiae 76, 551-580.

Strasser, A., Hilgen F.J. \& Heckel, P.H. 2007: Cyclostratigraphy - concepts, definitions, and applications. Newsletters on Stratigraphy (in press).

Strasser, A. \& Hillgärtner, H. 1998: High-frequency sea-level fluctuations recorded on a shallow carbonate platform (Berriasian and Lower Valanginian of Mount Salève, French Jura). Eclogae Geologicae Helvetiae $91,375-390$.

Strasser, A., Hillgärtner, H., Hug, W. \& Pittet, B. 2000: Third-order depositional sequences reflecting Milankovitch cyclicity. Terra Nova 12, 303-311.

Strasser, A., Hillgärtner, H. \& Pasquier, J.-B. 2004: Cyclostratigraphic timing of sedimentary processes: an example from the Berriasian of the Swiss and French Jura Mountains. SEPM Special Publication 81, 135-151.

Strasser, A., Pittet, B., Hillgärtner, H. \& Pasquier, J.-B. 1999: Depositional sequences in shallow carbonate-dominated sedimentary systems: concepts for a high-resolution analysis. Sedimentary Geology 128, 201-221.

Strasser, A. \& Védrine, S. 2007: Controls on facies mosaics of carbonate platforms: a case study from the Oxfordian of the Swiss Jura. IAS Special Publication (in press).

Thalmann, H. 1966: Gliederung und Fazies des obersten Malm (Reuchenetteund Twannbachformation) im südlichen Berner und Solothurner Jura. Eclogae Geologicae Helvetiae 59, 931-934.

Thurmann, J. 1830: Essai sur les soulèvements jurassiques du Porrentruy. Société d'Histoire Naturelle Strasbourg 1, 1-84.

Trümpy, R. 1980: Geology of Switzerland - a guide book. Part A: an outline of the geology of Switzerland. Wepf, Basel, $104 \mathrm{pp}$.

Vail, P.R., Audemard, F., Bowman, S.A., Eisner, P.N. \& Perez-Cruz, C. 1991: The stratigraphic signatures of tectonics, eustasy and sedimentology - an overview. In: Einsele, G., Ricken, W. \& Seilacher A. (Eds.): Cycles and Events in Stratigraphy. Springer, Heidelberg, 617-659.

Weedon, G.P. 2003: Time-series analysis and cyclostratigraphy. Cambridge University Press, Cambridge, $274 \mathrm{pp}$.

Weedon, G.P., Coe, A.L. \& Gallois, R.W. 2004: Cyclostratigraphy, orbital tuning and inferred productivity for the type Kimmeridge Clay (Late Jurassic), Southern England. Journal of the Geological Society London 161, 655-666.

Wildi, W., Funk, H., Loup, B., Amato, E. \& Huggenberger, P. 1989: Mesozoic subsidence history of the European marginal shelves of the Alpine Tethys (Helvetic realm, Swiss Plateau and Jura). Eclogae Geologicae Helvetiae $82,817-840$.

Manuscript received February 25, 2007

Revision accepted June 24, 2007

Editorial handling: Hanspeter Funk, Helmut Weissert, Stefan Bucher

Published Online First November 2, 2007 